\title{
What Is Known about the Immune Response Induced by Plasmodium vivax Malaria Vaccine Candidates?
}

\author{
Carolina López ${ }^{1,2}$, Yoelis Yepes-Pérez ${ }^{1,3}$, Natalia Hincapié-Escobar', Diana Díaz-Arévalo ${ }^{1,4}$ \\ and Manuel A. Patarroyo ${ }^{1,5 *}$
}

${ }^{1}$ Molecular Biology and Immunology Department, Fundación Instituto de Immunología de Colombia (FIDIC), Bogotá, Colombia, ${ }^{2}$ PhD Programme in Biomedical and Biological Sciences, Universidad del Rosario, Bogotá, Colombia, ${ }^{3}$ MSc Programme in Microbiology, Universidad Nacional de Colombia, Bogotá, Colombia, ${ }^{4}$ Universidad de Ciencias Aplicadas y Ambientales (UDCA), Bogotá, Colombia, ${ }^{5}$ Basic Sciences Department, School of Medicine and Health Sciences, Universidad del Rosario, Bogotá, Colombia

OPEN ACCESS

Edited by:

Irene S. Soares,

University of Sao Paulo, Brazil

Reviewed by:

Georges Snounou,

Centre National de la Recherche Scientifique (CNRS), France

Daniel Olive,

Institut national de la santé et de la recherche médicale, France

Josué Da Costa Lima-Junior, Oswaldo Cruz Foundation, Brazil

*Correspondence:

Manuel A. Patarroyo mapatarr.fidic@gmail.com

Specialty section:

This article was submitted to

Vaccines and Molecular

Therapeutics,

a section of the journal

Frontiers in Immunology

Received: 05 November 2016

Accepted: 25 January 2017

Published: 13 February 2017

Citation:

López C, Yepes-Pérez Y, Hincapié-

Escobar N, Díaz-Arévalo $D$ and Patarroyo MA (2017) What Is Known about the Immune Response Induced by Plasmodium vivax Malaria Vaccine

Candidates?

Front. Immunol. 8:126.

doi: 10.3389/fimmu.2017.00126
Malaria caused by Plasmodium vivax continues being one of the most important infectious diseases around the world; $P$. vivax is the second most prevalent species and has the greatest geographic distribution. Developing an effective antimalarial vaccine is considered a relevant control strategy in the search for means of preventing the disease. Studying parasite-expressed proteins, which are essential in host cell invasion, has led to identifying the regions recognized by individuals who are naturally exposed to infection. Furthermore, immunogenicity studies have revealed that such regions can trigger a robust immune response that can inhibit sporozoite (hepatic stage) or merozoite (erythrocyte stage) invasion of a host cell and induce protection. This review provides a synthesis of the most important studies to date concerning the antigenicity and immunogenicity of both synthetic peptide and recombinant protein candidates for a vaccine against malaria produced by $P$. vivax.

Keywords: malaria, Plasmodium vivax, immune response, antigenicity, immunogenicity

\section{INTRODUCTION}

Malaria is one of the most important vector-transmitted diseases, affecting a large part of the world's population. Around 214 million new cases appeared in 2015, and 438,000 people died from the disease. This disease is caused by parasites from the phylum Apicomplexa, genus Plasmodium, and

\footnotetext{
Abbreviations: Spz, sporozoites; RBC, red blood cells; NT, N-terminal; pexel/VTS, Plasmodium export element/vacuolar translocation signal; Mrz, merozoites; NFk $\beta$, nuclear factor kappa B; PRRs, pattern recognition receptors; PAMPs, pathogenassociated molecular patterns; MHC, major histocompatibility complex; NK, natural killer; IFN- $\gamma$, interferon gamma; TNF, tumor necrosis factor; LDH, lactate dehydrogenase; TAT, thrombin-antithrombin III; HNE, human neutrophil elastase; IL, interleukin; Th1, T helper 1; Th2, T helper 2; CXCL9, chemokine (C-X-C motif) ligand 9; CCL2, chemokine (C-C motif) ligand 2; CCL5, chemokine (C-C motif) ligand 5; Ig, immunoglobulin; i.v., intravenously; HLA, human leukocyte antigen; CSP, circumsporozoite protein; TRAP, thrombospondin-related adhesive protein; GPI, glycophosphatidylinositol; PNG, Papua New Guinea; LSP, long synthetic peptides; TLR, toll-like receptor; CpG, cytosine and guanine separated by one phosphate; GLA, glucopyranosyl lipid A; TSR, thrombospondin type 1 repeat; MSP, merozoite surface protein; ELISA, enzyme-linked immunosorbent assay; EGF, epidermal growth factor; HABPs, high activity binding peptides; AMA-1, apical membrane antigen-1; rPvAMA-1, recombinant Plasmodium vivax apical membrane antigen-1; Fc R-Fc, Fc-gamma receptors; PP, poly-proline; TCR, T-lymphocyte receptor; ADCI, antibody-dependent cell-mediated inhibition; DBP, Duffy binding protein; DARC, Duffy antigen receptor for chemokines; rDBP, recombinant Duffy binding protein; PBMC, peripheral blood mononuclear cell; RBP, reticulocyte-binding proteins; HARBPs, high affinity reticulocyte-binding peptides.
} 
is transmitted by the bite of a female mosquito from the genus Anopheles infected by the parasite (1).

Five species cause malaria in humans: $P$. falciparum, $P$. vivax, $P$. malarie, $P$. ovale, and $P$. knowlesi. Acute febrile disease symptoms appear 10-15 days after the bite of an infected mosquito. Initial symptoms include fever, headache, shivering, and vomiting; if not treated early on, and depending on the species responsible for the disease, severe anemia, metabolic acidosis, or cerebral malaria may be produced, and even lead to death (1).

Studying the proteins involved in $P$. vivax invasion has not been easy, mainly due to technical restrictions such as a lack of continuous culture in vitro, meaning that studying the parasite's biology has been limited, as well as the identification of new antigens and their evaluation in vitro $(2,3)$.

Infection by more than one Plasmodium species is usually omitted in routine diagnosis by microscopy $(4,5)$, leading to an overestimation of the amount of cases caused by coinfection in endemic areas and thus to treatment failure (6). Drug resistance since the first report in 1989 (7) has been increasing worldwide throughout Southeast Asia [Indonesia, China, Thailand, Papua New Guinea (PNG)], South America (the Brazilian and Peruvian Amazon region, Colombia), Africa (Madagascar, Ethiopia), Pakistan, and Turkey $(8,9)$.

Such resistance appears to be related to mutations regarding multidrug resistance 1 ( $\mathrm{mdr} 1$ ) gene and variation in the gene's number of copies, presumably due to selective pressure by firstline chloroquine treatment $(10,11)$.

Even though malaria caused by $P$. vivax has been considered benign (unlike that caused by P.falciparum), severe P. vivax malaria has emerged during the last few years with some cases leading to death (12-17). In spite of $P$. vivax malaria having a greater global distribution, it is still considered a neglected infection, thereby leading to socioeconomic impact factors being understated in endemic regions, causing more than US $\$ 2$ billion per year costs worldwide (18). The forgoing means that investment and efforts must be focused on developing a vaccine against $P$. vivax malaria.

Antigenicity studies arise from evaluating the immune response induced in individuals naturally exposed to the infection. On the other hand, immunogenicity assays evaluate in vitro or in vivo the immune response induced when vaccine candidates are used for immunization (Figures $\mathbf{1}$ and 2).

The present review summarizes classical studies that have been carried out to date concerning the antigenicity and immunogenicity of the most important proteins considered candidates for a vaccine against $P$. vivax malaria. Although the use of a singlestage protein is not enough to provide a successful sterile vaccine, it has represented an important advance in identifying hundreds of malarial antigens that can be combined to develop a multistage, multi-epitope sterile vaccine.

\section{MALARIA: INFECTION BY P. vivax}

Around $90 \%$ of the clinical cases presented are the result of infection by two of the most relevant species: $P$. falciparum or $P$. vivax. $P$. vivax malaria is the second most important around the world and is the most prevalent on the Asian and American continents. Such infection is characterized by relapses several years after the first infection, since a latent form called hypnozoite occurs during hepatic phase. This stage is difficult to diagnose, allowing the parasite to survive in the host for longer $(1,19,20)$.

Infection begins with the vector inoculating sporozoites $(\mathrm{Spz})$ into the host's skin; these Spz are motile and travel through the blood stream, later being carried to the liver. Sinnis et al. have named a "skin stage" of infection because they have proposed that this interaction between $\mathrm{Spz}$ and cells at the injection site means that Spz may remain in the injection site for $2-3 \mathrm{~h}$, maybe in hair follicles, giving rise to infective merozoites (Mrz) (21, 22). Regarding $P$. berghei expressing GFP (a rodent parasite), it has been observed that $\mathrm{Spz}$ have a random gliding-movement. Moreover, Spz glide into the skin, interacting with blood vessel walls. Lymphatic vessels also become invaded to drain lymph nodes near the injection site where some Spz can partially develop into exoerythrocytic stages (23-25).

Sporozoites migrate from the skin to liver cells (these becoming infected first) and then cross/traverse endothelial cells and use cell traversal machinery to pass through the endothelium, thereby beginning the hepatic stage that might go unnoticed clinically $(26,27)$. Some parasites remain as hypnozoites during this stage, and others go into the blood stream giving rise to the erythrocyte stage where the disease's clinical manifestations are presented.

The severity of the disease during the erythrocyte stage depends on various factors, such as the location of parasitized red blood cells (RBC) in the target organs, the local and systemic action of the parasite's bioactive products, pro-inflammatory cytokine production, as well as innate and adaptive immune system cytokine and chemokine regulators, and the activation, recruiting, and infiltration of inflammatory cells (28).

After invading the hepatocytes, each Spz replicates within the parasitophorous vacuole by a family of parasite proteins having an NT export motif called pexel/VTS (Plasmodium export element/ vacuolar translocation signal) (29-31). The circumsporozoite protein (CSP) enters the hepatocyte's cytoplasm using the pexel/ VTS motif and a nuclear localization signal to go into the nucleus. CSP in the nucleus induces the expression of the host's genes, where the NFk $\beta$ transcription factor controls the expression of genes involved in inflammation (32), controlling biological functions such as metabolic transport, the cell cycle, the immune response, and apoptosis, thereby creating a favorable setting for parasite growth (31).

The Plasmodium erythrocyte stage begins when an infected hepatocyte ruptures and releases close to 30,000 Mrz into the blood stream, undertaking an initial journey as merosomes to the lungs and then becoming disseminated in the circulation. Each Mrz infects an immature RBC (reticulocyte), which generates 16 new Mrz 48 h later (33).

\section{IMMUNE RESPONSE REGARDING MALARIA}

Innate and adaptive immune system molecules are involved in disease pathogenesis and control. Clinical immunity to malaria can be acquired during three phases: immunity to the disease, immunity to symptomatic infection, and partial immunity to 


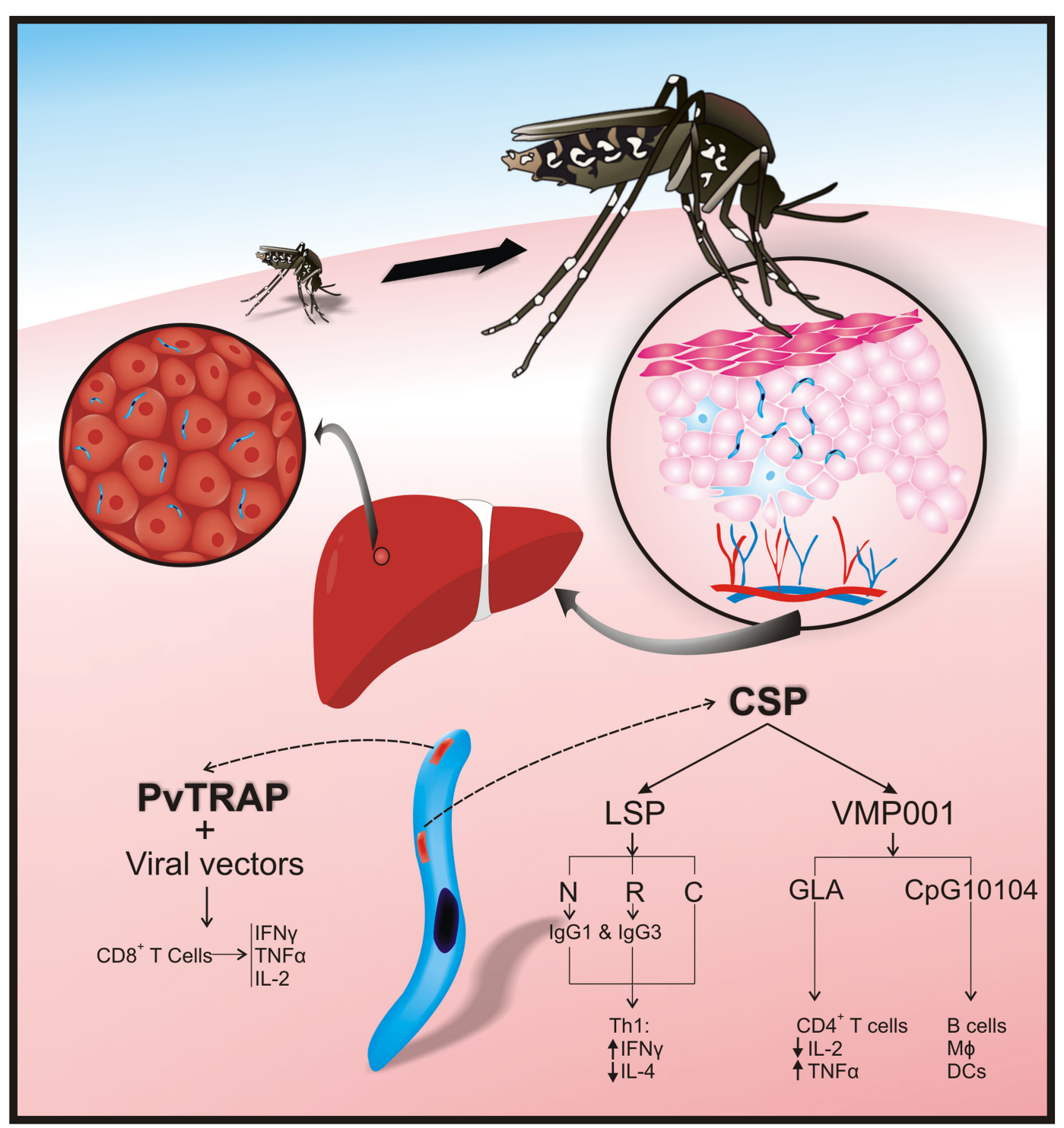

FIGURE 1 Plasmodium vivax preerythrocyte stage protein immunogenicity. After sporozoites have been inoculated into the skin by Anopheles mosquitoes, they travel to the liver via the bloodstream and enter hepatocytes thereby initiating the preerythrocyte stage. P. vivax circumsporozoite protein (CSP) and thrombospondin-related adhesive protein (PVTRAP) are involved in hepatocyte recognition and binding in a mammalian host. In CSP, the N-terminal (NT) and repeat region facilitate parasite binding to hepatocytes. Adaptive immune responses against PVCSP and PVTRAP control invasion of hepatocytes by cytokines [CD4+ T-helper 1 (Th1) and CD4+ T-helper 2 (Th2) cells], cytophilic antibodies, and CD8+ T-cells. Interferon gamma (IFN- $\gamma$ ) increases and interleukin (IL)-4 decreases after vaccination with CSP-long synthetic peptides [CSP-LSP-N terminal; CSP-LSP-R (repeat region), and CSP-LSP-N terminal]. Cytophilic antibodies (IgG1 and IgG3) are produced after vaccination with CSP-LSP-N; CSP-LSP-R. Immunization with PVCSP recombinant vaccine (VMP 001) combined with CpG10104 has induced protection and activation of B-cells, macrophages $(\mathrm{M} \Phi)$, and dendritic cells (DCs). When this recombinant vaccine is formulated with glucopyranosyl lipid $A(G L A)$, there is activation of CD4+ T-cells, production of tumor necrosis factor-alpha (TNF- $\alpha$ ), and reduction of IL-2. Immunization with PvTRAP, expressed in viral vectors, induces activation of CD8 T-cells and production of IFN- $\gamma$, TNF- $\alpha$, and IL-2.

parasitemia (28). The premunition (absence of fever with infection and lower densities of parasitemia) is present in places where malaria is endemic and in people that had suffered of several infections through the years (8-15 years), thus acquiring natural immune responses that lower the risk of clinical disease (34). The term was coined early in the 1900s during epidemiological studies with patients from endemic areas that can control the parasitemia and develop a subclinical infection (35). It is characterized by a slow acquisition rate, present just in holo- or hyper-endemic areas, rapidly lost, strain dependent, IgG dependent, and directed toward blood-stage parasites; although the immune response induced is strong, it is not a sterilizing immunity. The protection mechanism has not been completely described, but there is evidence that cytophilic antibodies and memory cells produced after repeated infections with Plasmodium variants are responsible for this kind of protection $(34,36-39)$. 


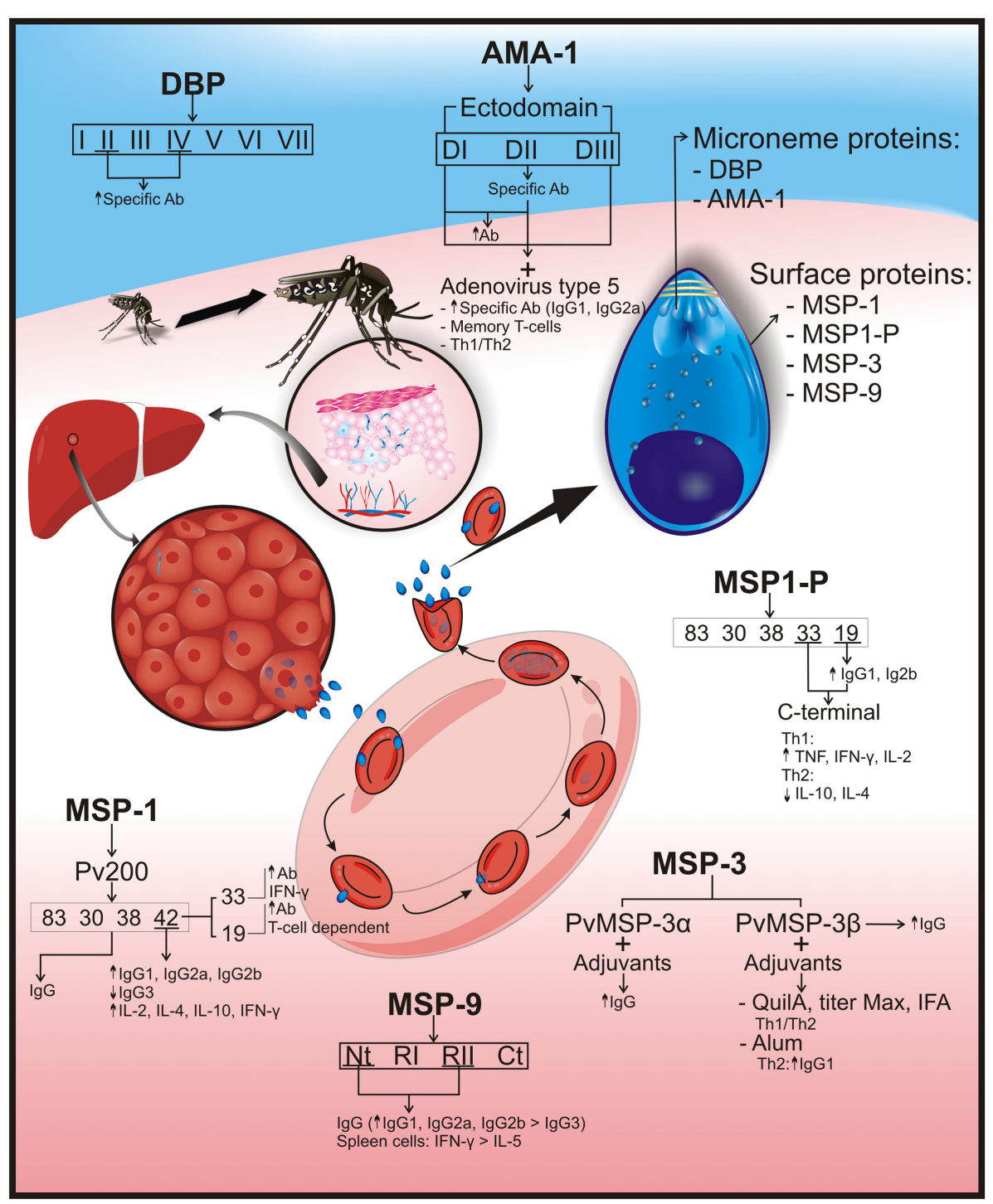

FIGURE 2 | Plasmodium vivax erythrocyte stage protein immunogenicity. P. vivax parasites are differentiated into tissue schizonts in hepatic cells, which, after thousands of replications, are released into the bloodstream as merozoites (Mrz). These Mrz predominantly invade reticulocytes, and their infection cycle is repeated every $48 \mathrm{~h}$. Several surface and microneme merozoite proteins have been identified as vaccine candidates. Surface proteins would include merozoite surface protein-1 (MSP-1/Pv200), which is an abundant ligand on merozoite surface and is essential for reticulocyte invasion. MSP-1 was cleaved into 83, 30, 38, 42 (33 and 19) kDa fragments; immunization with the complete protein induced IgG production. MSP-1-42 fragment increased IgG1, IgG2a, and IgG2b production but not that of IgG3, as well as interleukin (IL)-2, IL-4, IL-10, and interferon gamma (IFN- $\gamma$ ) production in vaccinated mice. Immunization with 19-kDa fragments produced high antibody titers that were T-cell dependent. Higher antibody and IFN- $\gamma$ production was observed after vaccination with the 33-kDa fragment. Another surface protein is merozoite surface protein-1 paralog (MSP1-P), which was also cleaved into 83, 30, 38, 42, 33 , and 19 kDa; the last two fragments (C-terminal region) induced a Th1 cytokine response profile, having high tumor necrosis factor (TNF), IFN- $\gamma$, and IL-2, but low IL-10 and IL-4 cytokines (Th2 profile). High IgG1 and lgG2b titers were observed in vaccinated animals with 19-kDa fragment. Merozoite surface protein-3 (MSP-3): PvMSP3- $\alpha$ block II is highly immunogenic and induces IgG production. The PVMSP-3 $\beta$ region with Quil A, Titer Max, or IFA adjuvants has produced a balanced Th1/Th2 response and IgG but became directed toward a Th2 response when formulated with Alum. Merozoite surface protein-9 (MSP-9) immune response against NT and repeat region II was mainly IgG, having greater IgG1, IgG2a, and IgG2b titers than IgG3 isotype production. These two regions also induced higher IFN- $\gamma$ than IL-5 production in spleen cells. The following are microneme proteins: the Duffy binding protein (DBP) is a surface receptor for invading human reticulocytes and is divided into seven regions where regions II (main ligand domain) and IV induce specific antibody production. Apical membrane antigen-1 (AMA-1) is essential during cell host invasion, and its ectodomain defines three subdomains (DI, DII, and DIII). Immunization with AMA-1 induced high IgG antibody titers. Vaccinating mice with human adenovirus type 5 and rAMA-1 have produced long-lived specific antibodies (IgG1 and IgG2a), memory T-cell, and Th1/Th2 balance immune responses. An arrow pointing upwards $(\uparrow)$ indicates an increase in antibody titers or cytokine production; an arrow pointing downwards $(\downarrow)$ shows reduced cytokine or antibody production. 
An innate immune response is triggered during Plasmodium infection as first line of defense, followed by an adaptive immune response, which includes T-cells, B-cells, and antibodies. A mosquito inoculates Spz into a host's skin when biting; these can remain in the skin for up to $6 \mathrm{~h}$ after inoculation (40). Such retention affects the place for antigen presentation and the location and type of response so induced.

Dendritic cells (DCs) present antigens, depending on the anatomic environment and the resulting immune response. These cells, through pattern recognition receptors, recognize the pathogen-associated molecular patterns (PAMPs) exhibited by the parasite. The mechanism of action regarding such recognition triggers intracellular signals enabling DC maturation (41). Three PAMPS have been described in P. falciparum: hemozoin, immunostimulatory nucleic acid motifs, and glycosylphosphatidylinositol anchors [glycophosphatidylinositol (GPI) anchors] (42).

The parasite's main source of protein is RBC hemoglobin. Hemoglobin hydrolysis releases lipophilic prosthetic groupheme-which is extremely toxic for the parasite. Heme detoxification is thus necessary and is achieved by converting heme into an insoluble crystalline material called hemozoin (Hz) (43). Regarding $P$. falciparum infection, $\mathrm{Hz}$ binds DNA inside host cell phagolysosomes and cytosol, and toll-like receptor (TLR)9 is activated by nucleic acids, NLRP3, AIM2, and other cytosolic sensors $(42,44-46)$.

In terms of AT content in the genome, $P$. falciparum has the highest AT content (82\%) and P. vivax the lowest AT content (56\%). On the other hand, in silico analysis has shown that $P$. falciparum contains $\sim 300 \mathrm{CpG}$ and $\sim 6,000$ AT-rich motifs and P. vivax $\sim 2,000 \mathrm{CpG}$ and $\sim 5,500$ AT-rich motifs. The release of CpG Plasmodium DNA into phagolysosomes produces an innate immune response activating TLR9 $(42,44,47)$.

Glycophosphatidylinositol anchors connect surface proteins with the protozoan plasma membrane; they are essential toxins for parasite viability (48). They turn on the innate response because they induce cytokine synthesis and are recognized by TLRs such as TLR1-TLR2 or TLR2-TLR6 (depending on GPI anchor activation containing three or two fatty acid chains, respectively) and TLR4 (49-51).

Some functions described for DCs have been $\mathrm{T}$ - and B-lymphocyte activation, immune tolerance, natural killer (NK) cell activation, and macrophage activation (52). For example, a third of $\mathrm{Spz}$ are drained to regional lymph nodes where they become internalized by skin-derived DCs (CD103+) and presented to CD8+ T-cells (26).

Some studies have shown that infected RBC bind to DCs, inhibit their maturation, and cannot stimulate a T-lymphocyte response in acute $P$. falciparum infection. Other studies have shown that inhibition depends on contacting a larger amount of infected RBC per DC $(53,54)$.

Antigens begin to be presented on hepatocyte surface during the hepatic stage in context of the major histocompatibility complex (MHC) class I molecules expressed on all nucleated cells to become recognized by CD8+ T-cells (55).

Immune response during the erythrocyte stage is mainly mediated by antibodies while a cellular response predominates during the hepatic stage (56). CD4+ T-, B-, and NK cells also play an important role in the immune response induced by the parasite during the erythrocyte stage since immunity depends on memory B-cell production and lifespan, following infection (57).

During $P$. vivax infection, some individuals can acquire immunity naturally; such immunity consists of a cytokine production-mediated cellular immune response, cytokine receptors, and proteolytic enzymes forming part of the host response to infection, as well as IgG antibodies. Patients having moderate parasitemia in endemic regions of Colombia have high IFN- $\gamma$ and TNF- $\alpha$ levels, a pro-inflammatory cytokine profile correlated with the response found in an unstable transmission region. The balance in interleukin (IL)-10/TNF- $\alpha$ rate could prevent increased parasitemia and host pathology (58).

A study by Hemmer et al. evaluated the production of lactate dehydrogenase (as hemolysis parameter), TNF- $\alpha$ (which produces a response to parasite products and has antiparasitic activity), thrombin-antithrombin III (pro-coagulant activity parameter), and human neutrophil elastase (its secretion becoming increased by parasite products, having antiparasitic activity) in a population infected by $P$. falciparum and $P$. vivax or $P$. ovale (59).

The parasitemia/response rate of each parameter was greater in patients suffering $P$. vivax or $P$. ovale malaria than $P$. falciparum; regarding parasitemia, TNF- $\alpha$ response was stronger in $P$. vivax or $P$. ovale infection than $P$. falciparum. The increase of these factors in $P$. vivax infection helped to control parasitemia, while they led to complications in P. falciparum infection such as host response-mediated severe malaria (59). Studies have shown that $P$. falciparum parasitemia levels decrease when coinfected with either P. vivax or other Plasmodium species, compared to single infection (60), thereby attributing a possible attenuating role to other P. falciparum species (60-62).

Another study that compared the immune response of patients suffering complicated and uncomplicated malaria caused by $P$. vivax reported a higher IFN- $\gamma / \mathrm{IL}-10$ rate in patients having complicated disease, as well as higher TNF- $\alpha$ level. They concluded that the severity of disease caused by $P$. vivax was correlated with pro-inflammatory immune response activation and cytokine imbalance (63).

Interleukin-10 acts as immunoregulator by controlling the effects of other cytokines produced by CD4+ Th1 and CD8+ T-cells in Plasmodium infection. The overproduction of cytokines such as IFN- $\gamma$ by these cells not only helps to increase phagocytosis for eliminating the parasite but also produces immunopathological effects associated with the disease. However, studies involving another group of patients suffering $P$. vivax malaria found high levels of IFN- $\gamma$ and IL-10 in patients with previous episodes of malaria. Polymorphism studies regarding the IL-10 gene promoter in populations from endemic regions have shown that polymorphisms neither influence the production of this cytokine nor its regulatory function regarding the immune response (64, 65).

Goncalves et al. evaluated the cytokine pattern in uncomplicated symptomatic $P$. vivax and $P$. falciparum infection in a low malaria transmission region in Brazil to test the hypothesis that $P$. vivax infection causes a greater pro-inflammatory cytokine response than infection by other Plasmodium species. They 
found a greater anti-inflammatory cytokine response than in $P$. falciparum infection, but similar pro-inflammatory cytokine response. The response of anti-inflammatory cytokines such as IL-10 and IL-10/TNF- $\alpha$, IL-10/IFN- $\gamma$ and IL-10/IL-6 ratios in clinical malaria caused by $P$. vivax was short-lived and positively correlated with parasitemia rather than with the symptoms. This means that there must be a balance between inflammatory cytokine and regulator responses (66).

Network analysis was one of the approaches adopted by Mendoca et al. for understanding the interaction between different blood biomarkers for inflammation, tissue damage, and oxidative stress and the immunopathogenesis of malaria. They concluded that when studying uninfected individuals from endemic regions, the network of interactions showed high density between these biomarkers, limiting the symptoms but not the infection. IL-10 and IL-4 have connections with chemokine (C-X-C motif) ligand 9 (CXCL9) in uninfected people and with chemokine ( $\mathrm{C}-\mathrm{C}$ motif) ligand 2 and IFN- $\gamma$ in people having asymptomatic $P$. vivax infection $(67,68)$.

Such interactions revealed a protective role for IL-4 and IL-10 cytokines due to their modulating effect on these proinflammatory cytokine and chemokine. The network of biomarkers in patients suffering mild malaria consisted of IFN- $\gamma$, tumor necrosis factor (TNF), and chemokine (C-C motif) ligand 5, while the interaction occurred between CXCL9 and IL-12 in symptomatic patients. CXCL9 was associated with regulatory cytokines thereby suggesting their role in resistance to infection, as well as being associated at the beginning with symptoms when linked to IL-12. Patients who had a fatal outcome regarding the disease had an interaction between TNF, IFN- $\gamma$, and IL-10, the latter modulating the Th1 response, negatively regulating TNF and IFN- $\gamma$, due to an IL-12p70 suppression that could lead to death $(67,68)$.

Cytokine profile variations have been observed in malariadengue coinfection. TNF levels have increased in patients with coinfection regarding single infection thereby highlighting the role of IL-6, INF- $\gamma$, and IL-7 (68). Regarding the humoral response, antibodies play an import role in protection against malaria, and this has been demonstrated in different studies. Cohen et al. showed that passive transfer of antibodies from malaria-immune individuals to naïve young children suffering severe clinical malaria reduced the parasite density and clinical symptoms related to this disease (69). This experiment was confirmed by further studies where adult patients controlled the clinical symptoms and parasitemia after receiving intravenously injections of sera from people living in malaria-endemic areas $(70,71)$.

Immunoglobulins can protect or arrest disease progression in different ways; neutralizing anti-Spz antibodies can block Spz from invading hepatocytes (72-74). Mrz can be opsonized in the erythrocyte stage by specific antibodies that activate cellmediated death or prevent the invasion of RBC and block the proteins responsible for binding to molecules on cell surface.

Studies in malaria-endemic areas have suggested that high IgG3 and IgG1 cytophilic antibody titers are associated with protection (75). In vitro studies have shown that monocytes can kill asynchronic malaria parasites in the presence of cytophilic IgG3 and IgG1 antibodies (76). These antibodies facilitate phagocytosis and kill Plasmodium parasites since cross-linked Fc $\gamma \mathrm{R}-\mathrm{Fc}$ induce a respiratory burst. Antibody responses against $P$. vivax CSP-1 (77), PvMSP-1 (78-81), PvRBP1 (82, 83), PvAMA-1 (84), and $P v$ MSP- $3 \alpha(85,86)$ have been characterized by IgG1 and IgG3 predominance, which are associated with malaria exposure and malaria protection; Tables 1 and $\mathbf{2}$ summaries the results obtained in each study.

\section{MHC Molecules and the Immune Response}

Major histocompatibility complex proteins have high polymorphism in human beings; antigen-binding capability varies from one allele to another, increasing or reducing their affinity (55). The forgoing is essential for developing an effective vaccine inducing a protective immune response.

Major histocompatibility complex antigen-presenting molecules are divided into two large groups. Class I present intracellular antigens and can couple eight to nine amino acidlong peptides due to the smaller size of their grooves. Class II recognizes extracellular antigens and can display 13-18 amino acid-long peptides (109).

The genes encoding class II MHC proteins in humans are called human leukocyte antigen (HLA) and are in chromosome 6. They have alpha and beta subunits, an immunoglobulin domain, and a short transmembrane portion. They have genes from three classes of protein: HLA-DP, HLA-DQ, and HLA-DR; the most polymorphic locus is HLA-DR at expense of a highly polymorphic beta subunit, unlike the alpha subunit, which is monomorphic in humans (110).

The peptide's binding site is formed by two almost parallel alpha helix regions above a beta sheet. The peptides are bound in the groove formed by the helices, with their terminal residues extended. The peptides adopt an extended poly-proline type II conformation exposing the peptide backbone to MHC conserved hydrogen-bonding residues covering the groove. Such conformation allows a peptide's side-chains to bind to the groove of the MHC binding site, as well as allowing the side-chains to bind to MHC pockets in positions $1,4,6$, and 9 . The others bind to the T-lymphocyte receptor (TCR)-binding site $(55,111)$.

Major histocompatibility complex class II molecules, expressed constitutively on antigen-presenting cell surface (DCs, macrophages, and B-lymphocytes) recognize extracellular peptides processed by the endosome/lysosome pathway, which are edited by the HLA-DM molecule. MHC class II presents the antigen to the TCR of CD4+ T-lymphocyte (T-helper) (55).

The CSP is one of the most important proteins described to date in Spz. Previous studies involving individuals residing in $P$. vivax malaria-endemic regions in Brazil have shown low responses for antibodies directed against the repeat region. An association has been reported between the HLA-DR16* allele and antibody response to $P$. vivax VK247 variant CSP repeats, as well as an association between the HLA-DR7* allele and a lack of antibody response to VK210 variant CSP repeats (112).

A study involving an infected population in Brazil evaluated the relationship between HLA-DRB1* alleles and the antibody 


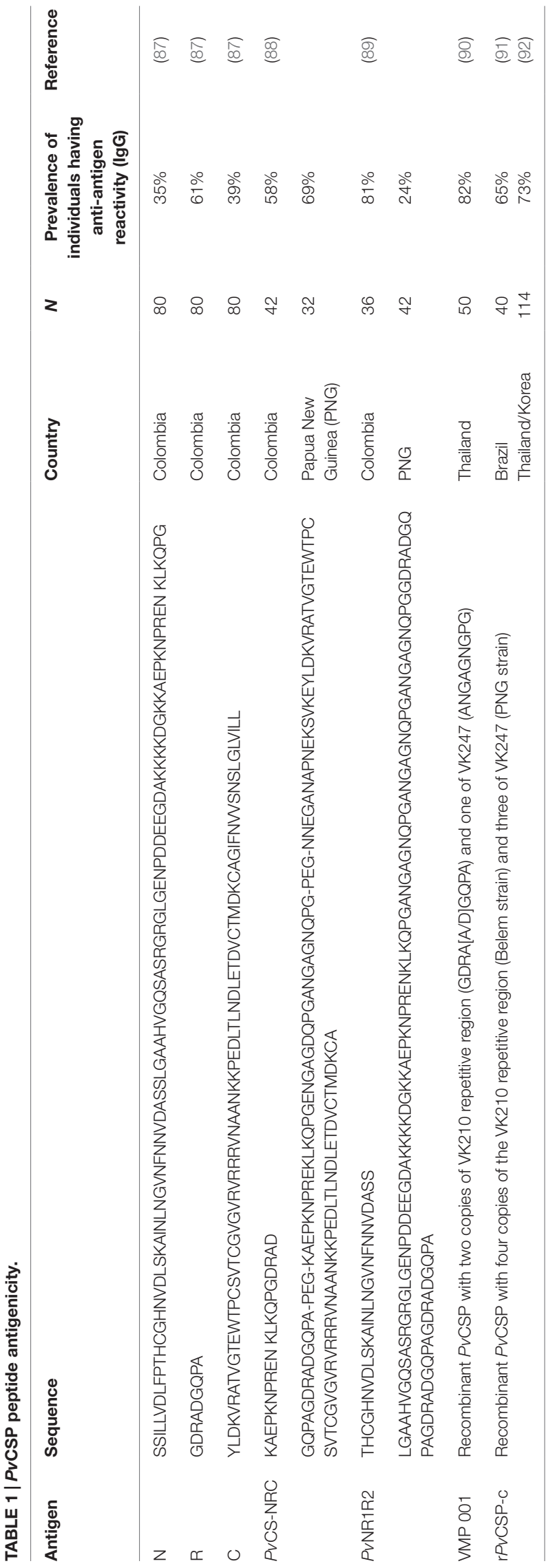

response to CSP, MSP-1, AMA-1, and Duffy binding protein (DBP) peptides. A significant association was found between high MSP-1 antibody levels (especially to the Pv200L fragment) and the HLA-DR3* allele; while no association was found between CSP, AMA-1, and DBP antibody production and HLA-DRB1* alleles (113).

During the erythrocyte phase, the merozoite surface protein (MSP) family is the responsible of the interaction between Mrz and reticulocytes. $P v \mathrm{MSP}-1, P v \mathrm{MSP}-3$, and $P v \mathrm{MSP}-9$ are potential vaccine candidates since they are exposed to the immune system and are recognized by antibodies from naturally infected individuals. A study by Lima-Junior et al. evaluated IgG antibody response to $P$. vivax MSP-1, MSP-3 $\alpha$, and MSP-9; a relationship between $\mathrm{HLA}-\mathrm{DRB} 1^{*} 04$ individuals and high antibody response to $P v \mathrm{MSP} 3_{\mathrm{CT}}$ and $P v \mathrm{MSP} 3_{\mathrm{NT}}$ and HLA-DQB1 $1^{\star} 03$ individuals, and response to $P v \mathrm{MSP} 3_{\mathrm{CT}}$ was observed (86).

IgG response was positively associated with $\mathrm{HLA}-\mathrm{DRB} 1^{\star} 04$ and HLA-DQB ${ }^{\star} 03$ individuals regarding $P v$ MSP- 9 repeat regions and the NT region. Such response involving high antibody levels was associated with a possible selective pressure by $P$. vivax in the Amerindian population. Antibody responses for $P v \mathrm{MSP}-9$ were more correlated with the time spent living in a malaria-endemic area and not with a particular HLA-DRB1* allele (86).

Ferreira et al. constructed and expressed a synthetic gene encoding promiscuous T-helper epitopes bound to the $P v \mathrm{RBP} 1_{435-777}$ sequence. Although it has been observed in clinical assays that candidates for a vaccine against $P$. vivax are poorly immunogenic, they predicted that this chimerical protein (called $P v$ RMC-RBP1) would be recognized by multiple HLA alleles. Epidemiological and serological studies proved the preservation of B-cell conformational epitopes in the chimeric protein. However, no association was found between HLA-DRB1* and HLA-DQB1* alleles and IgG antibody responses to the chimeric or native proteins. This seemed to be because $P v \mathrm{RBP} 1$ had multiple promiscuous T-cell epitopes, which did not induce specific genetic restriction (83).

\section{Non-HLA Host Polymorphism}

Miller et al. proved (for the first time) the hypothesis that the Duffy negative erythrocytes are resistant to $P$. vivax infection in Africans (114). The Duffy antigen or Duffy antigen receptor for chemokines (DARC) is expressed on RBC surface (115). Its encoding genetic locus having three alleles $\left[F Y^{\star} A\left(F y^{\mathrm{a}}\right)\right.$ and $F Y^{\star} B$ $\left(\mathrm{Fy}^{\mathrm{b}}\right)$ with SNP of differences and $F Y^{\star} O$ ] has a negative serological phenotype Fy(a-b-) $(116,117)$. The absence of DARC expression in RBC is due to a point mutation (T46C) in the GATA box of this gene's promoter $(118,119)$.

Duffy negative patients infected with $P$. vivax have been found during the last few years $(56,120)$. Mendes et al. reported that Duffy negative individuals from Africa's West Coast were infected with different strains of $P$. vivax, and they concluded that the parasite evolved quickly and used other receptors different to Duffy to invade RBC (121).

The balance between innate and adaptive immune response is important in the development of immunopathology and clinical severity in several infectious diseases. Sohail et al. have investigated polymorphisms in the TNF- $\alpha$ gene promoter region and 
TABLE 2 | Erythrocyte phase protein antigenicity.

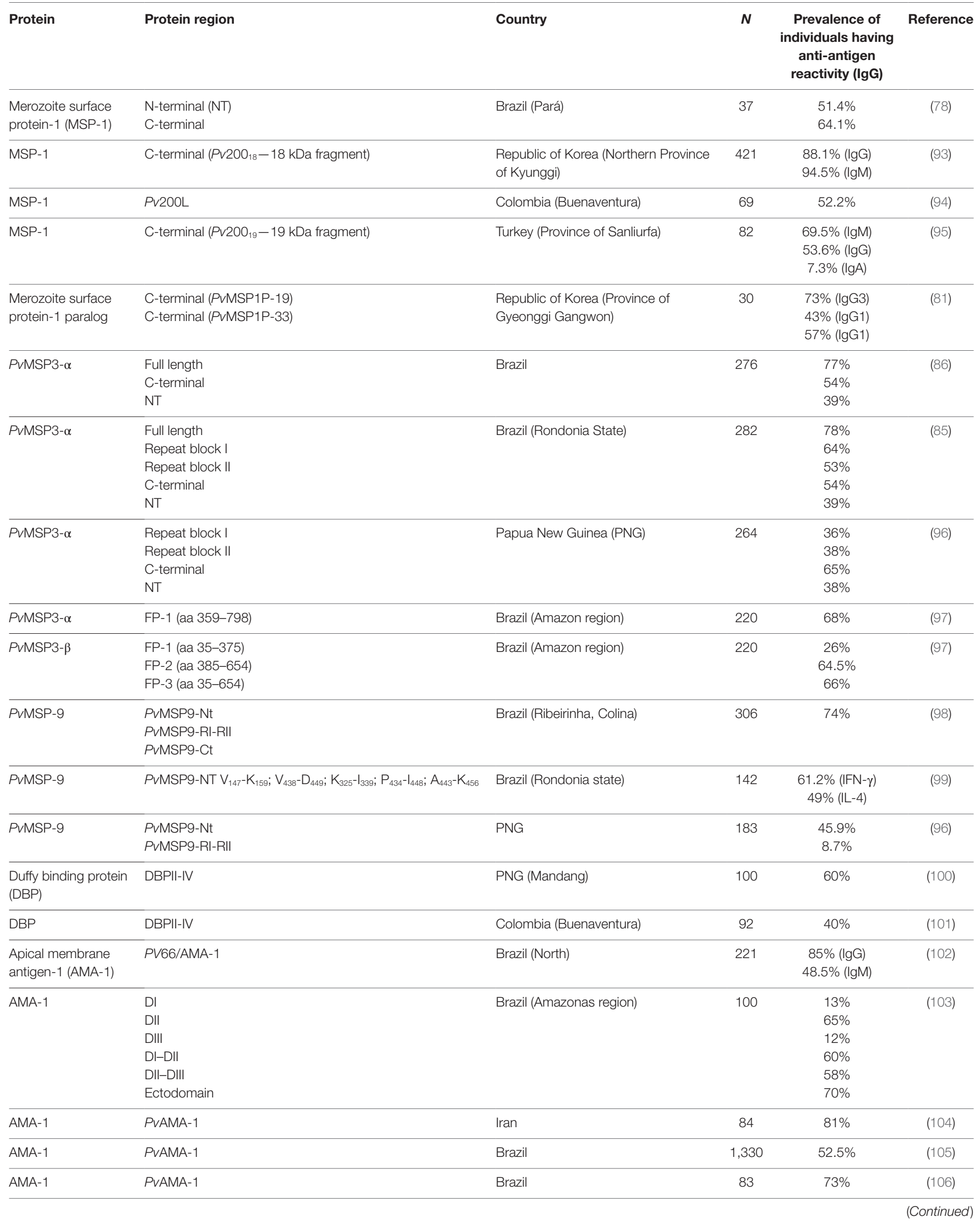


TABLE 2 | Continued

\begin{tabular}{|c|c|c|c|c|c|}
\hline Protein & Protein region & Country & $N$ & $\begin{array}{l}\text { Prevalence of } \\
\text { individuals having } \\
\text { anti-antigen } \\
\text { reactivity (lgG) }\end{array}$ & Reference \\
\hline PvRBP1 & $\begin{array}{l}\text { Full length } \\
\text { PVRBP1 }_{431-748} \\
\text { PVRBP1 }_{733-1407}\end{array}$ & Brazil (Rondonia state) & 294 & $\begin{array}{l}66 \% \\
41 \% \\
47 \%\end{array}$ & (82) \\
\hline PvRBP1 & $\begin{array}{l}P v R M C-R B P 1 \\
P_{V} R_{B P} 1_{23-751}\end{array}$ & Brazil (Rondonia state) & 253 & $\begin{array}{l}47 \% \\
60 \%\end{array}$ & (83) \\
\hline $\begin{array}{l}\text { PvRBP1 } \\
\text { PvRBP2 }\end{array}$ & $\begin{array}{l}\text { Coiled-coil and C-terminal peptides } \\
\text { Repeat sequence peptides } \\
\text { NT and repeat sequence peptides } \\
\text { Coiled-coil and C-terminal peptides }\end{array}$ & Republic of Korea & 16 & $\begin{array}{c}68 \% \\
62 \% \\
68-87 \% \\
62-68 \%\end{array}$ & (107) \\
\hline PvRBP1 & $\begin{array}{l}\text { PvRBP1a-34 } \\
\text { PvRBP1b-32 }\end{array}$ & Republic of Korea & 104 & $\begin{array}{l}34 \% \\
39 \%\end{array}$ & $(108)$ \\
\hline
\end{tabular}

its association with vivax infection in an Indian population. They found that TNF-308A and TNF-1031C were associated with vivax infection (very low frequency) in the study population (122). Other research has shown that IL1B, IL4R, IL12RB1, and TNF genes were associated with susceptibility to $P$. vivax malaria in a population from Brazil's Pará state, reporting -5,839C>T SNP promoter association with $P$. vivax malaria susceptibility (123).

Da Silva et al. have shown an Amazonian population's many host polymorphisms association with susceptibility or resistance to malaria infection. SNPs in the IL-10, CTL4 and TLR4 genes have been significantly associated with lower risk of clinical malaria, while a SNP in the IRF1 gene has displayed an enhanced risk. An intronic SNP in LTA was associated with protection, and one SNP on the TNF promoter was associated with susceptibility to clinical malaria (124).

Another study found no differences regarding IL6-176G $>C$ polymorphism distribution in participants making up the different clinical groups of vivax malaria in a Brazilian population. No association was found between TNF-308G and clinical manifestations of malaria and no haplotype having DDX39B (22 C>G and $348 \mathrm{C}>\mathrm{T}$ ) and TNF-308G > was identified or polymorphisms increasing the risk of clinical vivax malaria. Moreover, study participants having the genotype combination described here associated with resistance against manifestations of $P$. vivax infection (CG/CC/GG/GG) also had lower levels of pro-inflammatory TNF and IL-6, suggesting that DDX39B confers protection against malaria pathogenesis by reducing inflammatory response (125).

\section{P. vivax PREERYTHROCYTE PHASE PROTEIN ANTIGENICITY AND IMMUNOGENICITY}

\section{$P$ vivax CSP}

One of the predominant surface proteins in Spz is the CSP; it is expressed during the preerythrocyte phase and plays a fundamental role during hepatocyte invasion (126). This protein is a candidate for a vaccine against malaria in the preerythrocyte phase since various studies have shown that anti-CSP antibodies block hepatocyte invasion $(88,127,128)$.

Circumsporozoite protein in the different Plasmodium species has a highly conserved structure; it consists of an NT extreme $(\mathrm{N})$, a species-specific central repeat region (R) located between two conserved regions (region I and region II), and a GPI anchor in the C-terminal extreme (129). The repeat region contains an immunodominant B-cell epitope, which is associated with its immunogenic potential (130).

Furthermore RTS,S/AS01, the most advanced recombinant vaccine to date for preventing malaria caused by $P$. falciparum, is designed from $P$. falciparum circumsporozoite protein (PfCSP) repeat region peptides and $\mathrm{C}$-terminal region $\mathrm{T}$ - and $\mathrm{B}$-epitopes, coexpressed with hepatitis B surface antigen. Phase III clinical studies have shown $33-50 \%$ efficacy 1 -year post-immunization in 5- to 17-month-old infants $(89,92,131)$. However, after a 7 -year follow-up, the vaccine efficacy declined to $4.4 \%$, with a $16.6 \%$ efficacy against all episodes of clinical malaria in the low-exposure cohort and to $-2.4 \%$ in the high-exposure cohort (132). Furthermore, no vaccine efficacy was observed against severe malaria in children and young infants immunized with RTS,S/AS0 (133). Given that CSP has been widely studied in $P$. falciparum, and among different Plasmodium species, this protein is considered as a potential target for designing a vaccine against P. vivax (134-137).

Three allele variants of the $P$. vivax circumsporozoite protein ( $P v$ CSP) have been described: VK210, VK247, and vivax-like CSP-P, which differ at repeat region sequence level $(138,139)$. VK210 has greater global distribution, being found in countries like Brazil (140), India (141), Thailand (142), and Peru (143), while VK247 is found in some regions of Colombia and Brazil (144), and vivax-like CSP-P in Brazil (140), Indonesia, Madagascar, and PNG (139).

Antigenicity studies in people exposed to the disease in different endemic regions have found variable prevalence in individuals responding to different $P v$ CSP fragments (87) (Table 1). Preclinical studies and phase I clinical assays (Table 3 ) have been carried out regarding $P$. vivax with long synthetic peptides (LSP) 
having more than $70 P v$ amino acids from $P v$ CSP amino terminal $(\mathrm{N})$, carboxyl terminal $(\mathrm{C})$, and repeat $(\mathrm{R})$ regions linked to tetanus toxoid peptide (87). Immunized non-human primates from the genus Aotus spp. produced specific antibody response recognizing both LSP and CSP since the first immunization (87). LSP has also induced a Th1-type immune response characterized by increased IFN- $\gamma$ and reduced IL-4 production in T-lymphocytes stimulated in vitro $(87,137)$.

High IFN- $\gamma$ production in vitro and cytophilic antibodies (IgG1 and IgG3) capable of recognizing fragments from the $P \nu \mathrm{CSP} \mathrm{N}$ - and R-regions have been produced by LSP (as in experimental models) in phase I clinical assays. By contrast, the C-terminal region has not been immunogenic in humans (77).

Specific B- and T-cell epitopes must be included to stimulate an immune response thereby enabling recognition by class I and class II MHC molecules. Two modified LSP, PvCS-NRC (137 aa) and $P v \mathrm{NR}_{1} \mathrm{R}_{2}(131 \mathrm{aa})$ have induced a strong antigen-specific antibody response in immunized mice. They have inhibited $\mathrm{Spz}$ invasion of hepatoma cells (HepG2A-16) in vitro by 65 and $90 \%$ for both $P v \mathrm{CS}-\mathrm{NRC}$ and $P v \mathrm{NR}_{1} \mathrm{R}_{2}$, respectively $(88,128)$. $P v \mathrm{CS}$ NRC has included conserved regions I and II and the repeat region sequence from VK210 and VK247 variants $(88,129)$. $P v \mathrm{NR}_{1} \mathrm{R}_{2}$ has been improved by including $\mathrm{B}$-epitopes, $\mathrm{T}$-epitopes, and cytotoxic lymphocytes epitopes (128).

Immunogenic fragments of CSP have been evaluated in a recombinant vaccine (VMP 001) expressed in Escherichia coli encoding a $P v C S P$ chimera (149). VMP 001 has triggered a potent immune response in $\mathrm{BALB} / \mathrm{c}$ mice following a third immunization. The antibodies so produced were capable of agglutinating live Spz, indicating a loss of Spz-infective capability (150). $\mathrm{r} P v \mathrm{CSP}-\mathrm{c}$, a recombinant protein similar to VMP 001 (91), has shown antibody-specific reactivity against variants VK210 and VK247 (151).

Formulations have been made with adjuvants or TLR agonists to maximize vaccine candidate fragments' immune response. Regarding adjuvants, assays involving BALB/c mice and Aotus spp. monkeys have proved that formulation with Freund's, Montanide ISA270, and Montanide ISA51 adjuvants, which have not led to significant differences concerning specific antibody production. However, clinical assays have revealed greater immunogenicity (having greater antibody titers and IFN- $\gamma$ production) when

\begin{tabular}{|c|c|c|c|c|c|}
\hline Stage & Protein & Name & Type & $\begin{array}{l}\text { Clinical } \\
\text { trial }\end{array}$ & Reference \\
\hline \multirow[t]{2}{*}{ Preerythrocytic } & PvCSP & $\begin{array}{l}\text { CSP-N, } \\
-R,-C\end{array}$ & LSP & Phase lb & $(77,145)$ \\
\hline & PVCSP & VMP001 & Rec & $\begin{array}{l}\text { Phase } \\
\text { I, lla }\end{array}$ & $(146)$ \\
\hline \multirow[t]{2}{*}{$\begin{array}{l}\text { Transmission } \\
\text { blocking }\end{array}$} & Pvs25 & $\begin{array}{l}\text { ScPvs25/ } \\
\text { ISA51 }\end{array}$ & Rec & Phase I & $(147)$ \\
\hline & Pvs25 & $\begin{array}{l}\text { Pvs25H/ } \\
\text { Alhydrogel }\end{array}$ & Rec & Phase I & $(148)$ \\
\hline Erythrocytic & PVDBP & $\begin{array}{l}\text { ChAd63 } \\
\text { PvDBP }\end{array}$ & $\begin{array}{l}\text { Viral } \\
\text { vector }\end{array}$ & Phase la & $\begin{array}{l}\text { www. } \\
\text { clinicaltrials.gov } \\
\text { NCT01816113 }\end{array}$ \\
\hline
\end{tabular}

LSP, long synthetic peptide; Rec, recombinant; CSP, circumsporozoite protein.
Montanide ISA 51 adjuvant was used (145). Other adjuvant that has been tested is the inert nanoparticles, which is coated with the $P$. berghei CSP and induced CD8 T cell immunity without pro-inflammatory signals and also induced IFN- $\gamma$ production levels determined to be required for sterile protection in the $P$. berghei challenge model (152).

$P v$ CSP has been formulated with TLR agonists helping to improve the immune response. Aotus nancymaae immunized with VMP 001 plus a TLR9 agonist (CpG 10104) have produced high antibody titers since the first dose, antibodies directed against the C-terminal region, and the VK210 variant repeat region predominating. It was seen that $66.7 \%$ of immunized primates became protected following experimental challenge (153), associated with the activation of B-cells, macrophages, and DCs by the CpG 10104 agonist (154).

Other formulations have been evaluated by using new agonists. When using VMP 001 for immunization with the TLR4 agonist (glucopyranosyl lipid A) it was found that this created a CD4+ cell response with high IL-2 production but low TNF levels (90). Fusing a polypeptide covering the PvCSP immunodominant region coformulated with the FliC agonist (Salmonella typhimurium flagellin) produced a PAMPs-dependent immune response via TLR5 (155).

The results of $P v \mathrm{CSP}$ vaccine phase I/II of $P v(\mathrm{VMP} 001 /$ AS01B) have been published recently; it induced an antibody, cell-mediated immune response and delayed the latent period, but it did not induce sterile protection (146). Experience with $P$. falciparum vaccines has demonstrated that single-stage and single-target antigens cannot induce long-lived, sterile protection (133). The next generation $P$. vivax vaccine should include multiple targets, especially those needed for binding to host cells and those blocking transmission.

\section{Thrombospondin-Related Adhesive Protein (PvTRAP)}

The thrombospondin-related adhesive protein (TRAP) has also been evaluated as a potential preerythrocyte phase vaccine candidate. TRAP is a type I transmembrane protein, expressed in the micronemes and translocate to Spz surface during hepatocyte invasion. The ectodomain consists of an A domain, a thrombospondin type 1 repeat (TSR), and a repeat region, which is variable among species. The A and TSR regions are cell adhesion domains that interact with hepatocyte membrane receptors thereby enabling invasion (156-158).

This protein has been studied in $P$. berghei and $P$. falciparum as vaccine candidate; these studies showed a significant reduction in parasites during hepatic phase, mediated by CD8+ cytotoxic T-lymphocytes but involving low antibody production $(159,160)$ P. falciparum (161).

A $P$. vivax study with $P v$ TRAP LSP involved immunizing mice and Aotus spp., which were then experimentally challenged. A good antibody response against the peptide was produced in mice, but only 50\% recognized Spz. Four immunizations were needed in Aotus for obtaining a significant antibody titer, but IFN- $\gamma$ levels did not increase; four of the six monkeys became protected following experimental challenge (162). 
Mice immunized with $P v$ TRAP expressed in viral vectors have induced a better immune response associated with high IFN- $\gamma$ production and TNF- $\alpha$ by CD $8+$ T-lymphocytes and the production of high antibody titers specific against PvTRAP. A marked increase in IL-2 production from CD8+ lymphocytes has been seen after inoculating $\mathrm{Spz}$, indicating an active response in the liver (163).

One of the main problems in developing an antimalarial vaccine using $P v$ TRAP has been its high genetic polymorphism observed in different isolates from different regions around the world (164). An approach to preventing these problems would involve studying proteins' conserved regions instead of using immune-dominant antigens, which are highly polymorphic.

\section{$P$. vivax ERYTHROCYTE PHASE PROTEIN ANTIGENICITY AND IMMUNOGENICITY}

\section{Merozoite Surface Protein-1 (MSP-1)}

The MSP family has been the most studied candidate from the erythrocyte asexual phase when developing an effective vaccine against malaria. The MSP-1 belongs to this family, being one of the most studied and currently important for both $P$. falciparum and $P$. vivax (165).

The MSP-1 analog in P. vivax is encoded by the $P v 200$ gene (166), having a $200-\mathrm{kDa}$ molecular weight (167). The proteolytic processing profile is thought to be similar than for P. falciparum MSP-1, leading to 4 fragments: $83,30,38$, and $42 \mathrm{kDa}$; further cleavage of the last one (C-terminal region) produces 33 and $19 \mathrm{kDa}$ polypeptides, which are released to the blood stream. A $19-\mathrm{kDa}$ portion remained bound to the recently formed ring phase following reticulocyte invasion $(79,168)$.

A study in $P v$ exposed individuals found IgG responses to rPv200L (like the Pf190L fragment) indicating that the protein has high antigenicity. Sera from immunized animals showed IgG-specific antibodies capable of recognizing this protein $P v$. The authors highlighted the fact that the observed response had a protective tendency since Aotus spp. developed low parasitemia peaks following $P$. vivax challenge (94).

The $19-\mathrm{kDa} C$-terminal fragment has been one of the most studied from MSP-1 (Pv200). Kaslow and Kumar studied Pv200 protein immunogenic capability in mice vaccinated with three doses. An increase in antibodies was observed in sera, which became increased with the second vaccination, this being attributed to a booster for helping epitopes in $P v 200_{19}$. The response was T-cell dependent, suggesting that an immune response to a vaccine based on this protein could be boosted by natural infection (169).

Studies in an endemic area of Brazil by Soares et al. detected IgG antibodies against MSP-1 C-terminal and NT region. Response to the C-terminal region increased according to patients' number of previous episodes of malaria, an increase of up to $80 \%$ being observed in patients who had suffered more than four episodes. Moreover, in vitro proliferation was observed in $47 \%$ of the individuals and IFN- $\gamma$ production $54 \%$ of them. This study suggests that the $\mathrm{C}$-terminal region contains two immunogenic epidermal growth factor (EGF)-like domains which induce $\mathrm{T}$-cell and antibody responses against $P$. vivax during natural infection in humans (78). Later studies with the C-terminal region, specifically $P v \mathrm{MSP}-1_{19}$, have shown that these two EGF-like domains function as a binding portion in $P v \mathrm{MSP}-1$ interaction with erythrocytes (170).

Later studies by Soares et al. found that antibody titers against $P v$ MSP- $1_{19}$ became rapidly reduced (by up to 13 -fold) in infected individuals and those who had received treatment against the disease. Antibody response against the NT region became reduced, even though such reduction was not significant. The decrease of antibodies directed against the $\mathrm{C}$-terminal region could have contributed toward cases of reinfection in high-risk areas (171). Fernandez-Becerra et al. evaluated IgG subclasses in children, finding a predominant IgG1-type response against the C-terminal region and low IgG3 and IgG4 percentages. The predominant antibodies in adults were $\operatorname{IgG} 3$, a correlation between antibodies against the C-terminal region and age being observed (172).

High antibody titers against $P v 200_{19}$ have been observed in infected soldiers in the republic of Korea $P v$, mostly IgG and IgM to a lesser extent; these were maintained for a long period of time (from 4 to 6 months) following recovery from malaria (173). Another study showed that IgG antibody permanence was maintained for more than 5 months, while IgM-type remained negative 2-4 months after the onset of symptoms (93).

The major responses in Turkey (where $P$. vivax is the only Plasmodium species present in the area) were IgG, IgM, and IgA to a lesser extent. It is worth highlighting the fact that $P v \mathrm{MSP}-1_{19}$ was highly antigenic in individuals who are naturally exposed to the infection and, since no other Plasmodia are infecting in that area, the response observed cannot be attributable to a crossed reactivity (95).

Rosa et al. characterized the MSP- $1_{19}$ recombinant protein's antigenic and immunogenic properties together with two T-helper epitopes (the universal pan allelic DR epitope and a new internal MSP-1 epitope from the 33-kDa C-terminal region). It was seen that T-helper epitopes did not modify protein recognition by human IgG. The complete recombinant protein was immunogenic in marmosets (Callithrix jacchus jacchus), but only when Freund's adjuvant was used (174).

A study of immune response and protection was conducted in our institute, two groups of Aotus spp. (one splenectomized and the other not) were immunized with two recombinant polypeptides ( $\mathrm{rPvMSP}-1_{14}$ and $\mathrm{rPvMSP}-1_{20}$ ) from the MSP-1 $33-\mathrm{kDa} \mathrm{C}$-terminal region containing high activity binding peptides (HABPs) to reticulocytes. Most immunized monkeys recognized the $\mathrm{rPvMSP}-1_{14}, \mathrm{rP} v \mathrm{MSP}-1_{20}$, or the mix of HABPs by enzyme-linked immunosorbent assay (ELISA) and denatured $P v \mathrm{MSP}-142$ and $33-\mathrm{kDa}$ fragments by Western blot. Although half the animals immunized with the $\mathrm{rPvMSP}-1_{14}$ and $\mathrm{rP} v \mathrm{MSP}-1_{20}$ mixture were protected, some monkeys did not produce antibodies against the vaccine candidate. This suggested that protection was not only mediated by a humoral immune response (175). The next study involved vaccinating Aotus spp. monkeys with the two above mentioned recombinant polypeptides but in three doses. Aotus spp. produced antibodies capable of recognizing the native protein and managed to control parasitemia in four out of the five immunized 
monkeys. Interestingly, some animals produced high IFN- $\gamma$ levels and controlled parasitemia but displayed low antibody titers; conversely, some other animals were protected having high antibody tires but low IFN- $\gamma$ levels (176).

Other studies have found that anti-PvMSP-1 antibodies (predominantly IgG), recognizing the NT region, are associated with a reduced risk of infection and clinical protection against the $P v$ MSP-1. Although these antibodies do not recognize the C-terminal region (79), there have been reports that the C-terminal region is immunogenic and capable of naturally stimulating antibody production in new infections (78, 93, 173).

The MSP-1 protein's $42-\mathrm{kDa}$ fragment has also been studied due to its potential as vaccine candidate; its immunogenicity was evaluated in mice. High IgG1, IgG2a, and IgG2b antibody levels were observed while IgG3-type response was low. A high proliferative response also found high IL-2, IL-4, IL-10, and IFN- $\gamma$ levels being detected in culture supernatants (177). Greater prevalence of recognition of $P v \mathrm{MSP} 1_{19}$ than $P v \mathrm{MSP}_{42}$ was found when a naturally acquired humoral immune response was reported (178).

An MSP-1 paralog has been identified recently ( $P v$ MSP1-P); its immune response was characterized using different protein fragments $(83,30,38,42,33$, and $19 \mathrm{kDa})$. The NT $(83 \mathrm{kDa})$ fragment and two from the C-terminal region (33 and $19 \mathrm{kDa}$ ) were recognized by sera from infected patients living in endemic areas (179).

IgG1 and IgG3 (IgG2b in mice) were the predominant responses in patients from endemic regions, as in immunized mice. The $\mathrm{C}$-terminal region induced a predominantly $\mathrm{Th} 1$ profile of cytokine response having high TNF, IFN- $\gamma$, and IL-2, but low levels of IL-10 and IL-4 cytokines (Th2 profile), showed greater lymphoproliferative response than the MSP1-19 fragment. The correlation between parasitemia and anti-MSP1P antibody level suggest that it does not contribute strongly to inhibiting parasite growth (81).

Due to its colocation with MSP1, it has been thought that it played a similar role in erythrocyte invasion; however, analyzing the sequences has suggested different roles for each protein. Cytoadherence assays demonstrated that MSP1-P could be an essential adhesion molecule regarding $P$. vivax invasion to erythrocytes, is immunogenic in humans, and is a potential vaccine candidate against $P$. vivax (179).

\section{Merozoite Surface Protein-3 (MSP-3)}

The $P$. vivax merozoite surface protein-3 ( $P v \mathrm{MSP} 3)$ is a member of the MSP family characterized by having a highly polymorphic alanine-rich central domain (180). It has a relatively conserved $\mathrm{N}$ and C-terminal domain and two central blocks of seven repeats forming tertiary supercoiled helices in their structure (180-182). It is expressed in schizonts and is associated with Mrz surface during the erythrocyte phase (180).

Its homolog in $P$. falciparum has been studied as a vaccine candidate in preclinical (183) and phase I assays, protection was associated with reduced parasitemia by cytophilic antibodies inducing antibody-dependent cell-mediated inhibition of parasite growth mechanism (184). It has been shown to be highly immunogenic in $P$. vivax, having a high prevalence of antibodies directed against $P v \mathrm{MSP}-3 \alpha$ block II (96).

A correlation has been described between time spent living in an endemic region and the number of previous episodes of malaria, involving an increase in IgG1 and IgG3 anti-PvMSP-3 $\alpha$ $(85,86,96)$. A naturally acquired response has been found toward 15 antigenic determinants, mainly located in repeat regions (85). Other studies have reported the C-terminal region as being the most antigenic, having a significant increase in IgG in a population from Brazil (97) and PNG (96). However, it has been found the antibodies directed against block II are associated with protection against clinical episodes of $P$. vivax malaria, having greater than 500 parasites/ $\mu \mathrm{L}$ parasitemia (96).

Interestingly, no response against $P v \mathrm{MSP}-3 \alpha$ was produced in immunogenicity studies with C57BL/ 6 mice, while high antibody titers were produced with PvMSP-3 $\beta$ following the second and third immunization (97). Incorporating adjuvants (Quil A, TiterMax, or IFA) has maximized the response against $P v \mathrm{MSP}-3 \alpha$, indicating that another parasite's molecules must act as adjuvant for $P v \mathrm{MSP}-3 \alpha$ antigenic presentation during natural infection (96, 97). Regarding cellular response, $P v$ MSP-3 $\beta$ with Quil A, Titer Max, or IFA adjuvants have produced a balanced Th1/Th2 response, while the Alum adjuvant directed response toward Th2 with a significant murine IgG1 increase. Alum co-formulated with the TLR9 agonist (CpG ODN 1826) balanced the Th1/Th2 relationship, increasing Th1 response due to pro-inflammatory cytokine production (97).

\section{Merozoite Surface Protein-9 (MSP-9)}

The $P$. vivax merozoite surface protein-9 ( $P v \mathrm{MSP}-9)$ is also a potential vaccine candidate. Some studies have shown that this protein is conserved among Plasmodium species infecting humans, rodents, and primates. Furthermore, antibodies produced against $P v$ MSP9 homologs in P. cynomolgi and $P$. knowlesi can inhibit Mrz invasion of erythrocytes (180).

The $P$. vivax, $P$. knowlesi, and $P$. cynomolgi msp-9 genes encode a hydrophobic signal peptide and repeat motifs upstream of the stop codon and a C-terminal region having two species-specific blocks of repeat amino acids (PvMSP9-RI and PvMSP9-RII). Together with $P$. falciparum has four cysteine residues close to the NT giving the MSP-9 family's structural and functional characteristics. This protein is expressed during schizogony and is organized on Mrz surface during schizont development and segmentation $(180,185)$.

The cellular and humoral immune response of BALB/c mice immunized with PvMSP9-Nt, PvMSP9-RII recombinants, and the mixture of both recombinants was evaluated for testing $P v$ MSP-9 immunogenicity. Antibody response in mice was determined by ELISA and was mainly IgG; there were greater titers for IgG1, IgG2a, and IgG2b isotypes than IgG3. Regarding cellular response, the amount of spleen cells secreting IFN- $\gamma$ was higher than those secreting IL-5. Moreover, sera from patients living in an endemic region of Brazil recognized the two recombinant regions, demonstrating that both were immunogenic (186).

A study was carried out on a population, which was naturally exposed to $P$. vivax infection in Brazil, and the immune response against $P v$ MSP9-RIRII and $P v$ MSP-N terminal domains was 
evaluated. Of the 306 individuals in this study, 74\% had IgG antibodies that recognized at least one of the recombinant proteins, thereby indicating that these proteins are antigenic during natural infection, especially $P v$ MSP9-RIRII. When the IgG subclasses were evaluated, IgG1 was predominant for $P v$ MSP9-RIRII and $P v$ MSP9-N terminus, and IgG2 was prevalent for PvMSP9RII. Furthermore, five synthetic peptides predicted to bind to HLA-DR alleles were chosen, and the overall cellular response frequency for at least one of the peptides was $58 \%$ for IFN- $\gamma$ and $41 \%$ for IL- 4 . No association was found between IFN- $\gamma$ production and IgG levels regarding recombinant proteins. Lima-Junior et al. thus concluded that PvMSP9 C-terminal and NT domains are immune response targets for individuals living in $P$. vivax endemic regions. The reactivity index for IgG has been positively correlated with time spent living in an endemic area; conversely, IgG3 reactivity did not predominate regarding response to the recombinant proteins. It has been shown that $P v \mathrm{MSP} 9 \mathrm{NT}$ region peptides induce memory T-cell response where IFN- $\gamma$ and IL-4 cytokines produced in significant proportion by individuals from endemic regions has indicated the presence of T-cell epitopes (98).

Another study involving volunteers from an endemic region of the Amazon region showed that the response of cells producing IFN- $\gamma$ was significantly greater than those regarding IL-4. The results obtained for 5 of the 11 peptides selected contained $P v$ MSP 9 promiscuous T-cell epitopes. The core sequence (ASIDSMI) shared by three of the peptides was highly immunogenic; another peptide could have had two immunodominant epitopes, one in the overlapping core region and another in the C-terminal region, which produced a cellular response in 23 volunteers (99).

The specific response of IgG to PvMSP9-N terminal has been associated with protection against symptomatic $P$. vivax infection in children aged less than 3 years old in a PNG endemic region. Such antibodies specific for PvMSP9 were prevalent in children suffering frequent infections and have been associated with protection in children who have not had these infections. The authors concluded that two classes of antibodies are produced against the $P v \mathrm{MSP} 9 \mathrm{NT}$ region, one produced by short-lived memory B-cells and the other by long-lived cells (96).

\section{Duffy Binding Protein (DBP)}

Plasmodium vivax Mrz requires antigens from the Duffy blood group as surface receptor for invading human reticulocytes (114). P. vivax DBP adhesion to its receptor on erythrocytes [Duffy antigen receptor for chemokines (DARC)] is essential for the parasite to continue developing during the asexual phase in human blood $(114,187) . P v \mathrm{DBP}$ is a $140-\mathrm{kDa}$ protein, which is located in the micronemes; it has been divided into four important regions: a peptide signal sequence (region I), two cysteine-rich regions separated by a non-homologous hydrophilic region (region II, identified as the erythrocyte-binding domain, and region VI), and transmembrane domain (region VII) (188-191). PvDBP is a main target to use as vaccine candidate since its importance during parasite invasion and its ability to induce antibodies against the parasite's asexual phases $(114,192)$.

Serological evaluation in a PNG endemic area has shown that a humoral immune response was common and increased with age, suggesting a possible booster effect regarding antibody response in some cases by repeated exposure to the infection (100). A similar pattern has been observed in an endemic region of Colombia where a positive correlation was found between increased antibody response and patients' age. Also, an immunologic boost for DBP was found, even in endemic areas having a low transmission level (101). The forgoing shows that $\mathrm{DBP}_{\text {II }}$ was naturally antigenic in people residing in endemic regions.

Children having high antibody levels against $\mathrm{DBP}_{\mathrm{II}}$ has been associated with delayed reinfection time with the same $P$. vivax variant; however, such association was not observed when evaluating MSP1-19 (193). In other studies have been observed that naturally acquired neutralizing antibodies against DBP are short-lived, increasing with acute infection, and are strain specific $(194,195)$.

Antibodies from plasma from naturally exposed people and from animals immunized with recombinant Duffy binding protein (rDBP) have blocked the specific interaction between the $P v$ DBP ligand domain in vitro and its receptor on erythrocyte surface; such inhibitory activity has been correlated with antibody titers $(196,197)$. The forgoing shows DBP's potential as vaccine candidate due to its essential role as adhesion molecule (196).

The cytokine production of individuals exposed to $P$. vivax was analyzed; IFN- $\gamma$, IL-10, and IL-2 induction was observed. The response was seen to depend on individuals' age and the specific $\mathrm{DBP}_{\text {II }}$ variant, producing partially acquired immunity to $P$. vivax in these populations (198). Similarly, epitopes mapped from the $\mathrm{DBP}_{\mathrm{II}}$ critical binding region have produced a humoral response, accompanied by increased antibody levels associated with patients' increased age, suggesting recognition through repeated infection. Some individuals recognized $\mathrm{rDBP}_{\mathrm{II}}$ but not linear epitopes, indicating the presence of conformational epitopes; such cases occur regularly in young people or subjects suffering first acute $P$. vivax infection, suggesting that multiple infections are needed for the recognition of linear epitopes (199).

The DBP binding domain $\left(\mathrm{DBP}_{\mathrm{II}}\right)$ is polymorphic, tending to compromise the efficacy of any vaccine associated with strainspecific immunity (192). Due to the high rate of polymorphism observed in DBP region II, an in-depth investigation was made of the relative importance of conserved and polymorphic residues in this region by directed mutagenesis. The mutations causing the loss of ligand function were mainly produced in discontinuous groups of conserved residues, while almost all mutations in polymorphic residues did not alter RBC binding (200). Such polymorphism has been seen to have a synergic effect on the antigenic nature of DBP (201). Sera from patients reacted to denatured, non-reduced, and native rDBP, indicating immunogenic conserved linear B-epitopes (100). The immune efficacy of a $\mathrm{DBP}_{\mathrm{II}}$ vaccine depends on inducing antibodies, and this response should be optimized toward conserved epitopes to protect against P. vivax (197).

Since DBP region II epitopes have been shown to be immunogenic, studies have established universal epitopes, which can be presented by different HLA-DR alleles inducing an effective cellular and humoral immune response, making them a candidate for a subunit-based vaccine (202). Antigenicity studies using $P v \mathrm{DBP}_{\text {II }}$ universal epitopes have shown that lymphoproliferation, 
IL-6, and IFN- $\gamma$ production is induced in peripheral blood mononuclear cells (PBMCs) from individuals exposed to infection. Such results have suggested that these epitopes having affinity for HLA-DR molecules can be good components of a vaccine against P. vivax (203).

Polymorphisms observed in DARC have also been associated with $P$. vivax infection severity and susceptibility in humans. Individuals with low DARC expression (a single negative allele) have a greater probability of having anti-MSP1 and anti-DBP antibodies than individuals having high DARC expression (double positive alleles). Individuals having high expression of DARC have been found to be associated with greater susceptibility to infection, exhibiting low frequency and magnitude of specific antibody response against $P$. vivax during the blood stage. This could indicate that one of $P$. vivax's primary mechanisms for evading host immunity works through indirect negative regulation of DARC, influencing the humoral response against erythrocyte invasion and parasite development (204).

\section{Apical Membrane Antigen-1 (AMA-1)}

The AMA-1 in Plasmodium is a transmembrane protein, which is localized in the micronemes. It seems to be essential during cell host invasion and is present in all Plasmodium species (205, 206). Eight disulfide bonds have been identified in the AMA-1 ectodomain of $66 \mathrm{kDa}$, defining three different subdomains (DI, DII, and DIII) (207). Immune responses induced by AMA-1 from different Plasmodium species have shown potent parasiteinhibitory effects both in animals and in vitro thus suggesting AMA-1 as a potential vaccine candidate (208).

Plasmodium vivax AMA-1 ectodomain (PV66/AMA-1) has been shown to be highly immunogenic in rhesus monkeys, inducing high IgG antibody titers; however, these suffer a rapid decline. A slight reduction in parasitemia has been observed in $P$. cynomolgi-challenged animals previously immunized with $P V 66$ (209).

Mice immunized with human adenovirus type 5 and rAMA-1 have produced long-lived specific antibodies (including IgG1 and IgG2a) and memory T-cell proliferative responses. Memory T-cell responses were effector- and central-type, central memory predominating (210). In mice it was observed that response was both Th1 and Th2 following three immunizations and persisted for 1 year following the first immunization. On the other hand, the antibodies produced were capable of recognizing the native protein located on $P$. vivax parasites (211).

When evaluating the immune response against two $P v A M A-1$ variants $(A$ and $B)$, there were no significant differences regarding the prevalence of IgG response. A marked switching in isotypes, which became increased with age, was also seen. The predominant cytophilic antibodies recognized PvAMA1A (IgG1) and PvAMA1B (IgG1-IgG3). The immune-epidemiological data in this research were similar regarding the two variants, this implied that one of these forms could be used in a universal erythrocyte stage PvAMA-1 antigen-based vaccine (212).

An IgG response was observed in people residing in endemic regions exposed to $P$. vivax in Brazil, IgG1 being the dominant subclass. This antibody response was slightly lower than that observed with $\mathrm{MSP}_{19}$ and increased by $100 \%$ in individuals having had more than three episodes. Sequences of $P v A M A-1$ variable domain from different isolates have been seen to have limited polymorphism in this country (102).

This protein has been seen to be involved in Mrz invasion and contains an extracellular portion containing three different domains (207). When evaluating DI, DII, and DIII, separately or in combination in $P$. vivax-infected individuals, a greater immune response toward proteins containing the domain II was observed. Inhibition assays using the PvAMA-1 ectodomain led to common epitopes being identified within the DI-DII domains, which were recognized by antibodies from people residing in endemic regions. Immunization in mice having the PvAMA-1 ectodomain induced high levels of antibodies, predominantly against DI-II (103).

A linear B-epitope was also identified between amino acids 290-307 (SASDQPTQYEEEMTDYQK) in domain II, this peptide was recognized by sera from individuals naturally infected by $P$. vivax (213).

Recombinant $P$. vivax apical membrane antigen-1 DII was formulated with six adjuvants and was highly immunogenic regardless of the adjuvant used. DII-specific antibodies recognized native AMA-1 protein, demonstrating that it is immunogenic and indicating that this protein region could be evaluated as part of a subunit-based vaccine against malaria caused by $P$. vivax (214).

\section{Reticulocyte-Binding Proteins (RBP)}

Reticulocyte-binding proteins include $P v \mathrm{RBP} 1$ and $P v \mathrm{RBP} 2$ and their variants $P v$ RBP $1 \mathrm{a}$ and $\mathrm{b}$ and $P v \mathrm{RBP} 2 \mathrm{a}, \mathrm{b}$, and $\mathrm{c}$, and other family members (215). RBP1 is a homodimer bound by disulfide bonds, binds non-covalently to RBP2, and forms a protein complex (216). They are colocalized in the apical zone in Mrz micronemes and contain a transmembrane domain toward the C-terminal extreme, possessing repeat regions in $P v \mathrm{RBP} 2$ and reticulocyte-binding domains (108, 215, 217-219).

It is thought that RBPs could participate in reticulocyte invasion since no infection by $P$ vivax has been observed in mature erythrocytes (220). Their reticulocyte-binding ability has also been reported, but the specific receptors have yet to be identified (219). It has recently been found that only $P v R B P 2 b$ binds specifically to reticulocytes (221). Due to their participation in infection, they have been studied as erythrocyte phase vaccine candidates, aimed at blocking Mrz invasion of reticulocytes (218).

High affinity reticulocyte-binding peptides (HARBPs) have been identified, 5 in a fragment from the region I of $P v$ RBP1 NT extreme (222) and 24 throughout the whole protein (223). The highly-conserved region III (between amino acids 1,941-2,229) had the greatest amount of HARBPs (223) and, when used as immunogen, it induced high antibody titers in Aotus nancymaae monkeys, able to recognize the full $P v \mathrm{RBP} 1$ in parasite lysate. T-lymphocytes became activated following the second and third doses, but no protection was obtained after experimental challenge (224). Due to studies involving other $P$. falciparum proteins showing that highly conserved sequences are not immunogenic, in spite of having high binding capability, it has been suggested that changes must be made in some amino acids to increase the immune response and induce protection based on studies of critical binding residues for HARBPs from region III (224). 
Antigenicity studies have found a direct relationship between higher anti- $P v \mathrm{RBP} 1$ antibody titers and the number of previous episodes, the time spent residing in an endemic region and age $(82,83,219,224)$. The immune response to $P v R B P 1$ has also been associated with greater IgG1 and IgG3 cytophilic antibody presence against fragments from polymorphic regions $(82,83)$.

Studies regarding different populations where an acquired response to B-epitopes (107) and various fragments from $P v$ RBP1 and $P v \mathrm{RBP} 2$ variants $(108,219)$ have shown high prevalence of IgG antibodies against fragments from repeat region, the supercoiled helix, and $P v$ RBP1 C-terminal region (107) (Table 2). Regarding the NT region (including the most polymorphic region of the $P v \mathrm{RBP} 1 \mathrm{a}$ and $\mathrm{b}$ variants) (108), IgG prevalence was intermediate in a population from Thailand, while no antibody response against $P v \mathrm{RBP} 1 \mathrm{~b}$ was found in a population from the Republic of Korea (219).

On the other hand, $P v$ RBP2 has been seen to have greater antibody prevalence against NT region, repeat region (107), and $P v \mathrm{RBP} 2 \mathrm{c}$ variant fragments (219). $P v \mathrm{RBP} 2 \mathrm{c}$ is one of the most polymorphic variants, probably having the greatest global distribution, associated with the prevalence of this variant's recognition (219). $P v$ RBP $2 \mathrm{~b}$ and $P v \mathrm{RBP} 1$ a have been correlated with lower risk of parasitemia in a cohort study of PNG children (221). Regarding other proteins such as $P v \mathrm{DBP}, P v \mathrm{RBP}$ antigenicity is much lower $(82,108)$.

\section{Antigenicity and/or Immunogenicity of Non-Classical Vaccine Candidates}

In spite of the technical limitations involved in studying $P$. vivax proteins, other proteins characterized as being promising vaccine candidates have been studied during the last few years. One such is merozoite surface protein-10 ( $P v \mathrm{MSP} 10)$ having NT and C-terminal regions with two EGF-like domains and a GPI anchor (225). Colombian individuals exposed to $P$. vivax infection have shown reactivity to recombinant $P v \mathrm{MSP} 10$; $\mathrm{r} P v \mathrm{MSP} 10$ has also elicited high antibody titers against the protein in immunized Aotus monkeys but no protection after challenge (226). Infected Korean individuals had 42\% IgG prevalence, IgG1 and IgG3 antibodies predominating. Immunized mice have shown a Th1 response-biased immune response (227).

The $P v 34$ protein was characterized based on homology of the $P$. falciparum $P f 34$ protein, and antigenicity was evaluated in PBMCs from individuals previously exposed to infection. Stimulation with $\mathrm{rPv} 34$ induced proliferation in $71 \%$ of individuals and high IL-2, IFN- $\gamma$, and IL-4 production (Th1/Th2 profile), such response being attributed to recognition of T- and B-epitopes responsible for a combined immune response (228).

Another protein characterized was $P v$ RON-1, based on its homologous PfASP protein in P. falciparum. This protein's antigenicity was evaluated using sera from people having had previous $P$. vivax infection. The results showed that $P v \mathrm{RON}-1$ was expressed during natural infection and could generate an antibody response in the host (229).

An antigenicity and immunogenicity study of $P$. vivax rhoptryassociated leucine (Leu) zipper-like protein-1 (PvRALP-1) was carried out on patient serum samples and immunized mice.
$P v$ RALP-1 was recognized in samples from patient sera, IgG1 and IgG3 being the predominant subclasses, although without significant differences with the other subclasses; Th1/Th2 response was balanced in immunized mice (230).

The CelTOS microneme protein characterized and tested for $P$. falciparum, having $98 \%$ homology with $P$. vivax, should be considered for further studies since cross-species protection has been demonstrated in preclinical studies (231). It has been described as vaccine target by blocking transmission infection or preerythrocytic stage due to its cell traversal function in $\mathrm{Spz}$ and ookinetes (232). A recent study proved $\sim 20 \%$ prevalence of antibodies against $P v$ CelTOS in a Thai population (233). More studies related to immunogenicity, and antigenicity potential are needed and should involve new proteins characterized during the last few years, related to host cell invasion during different life cycle stages, such as rhoptry neck proteins.

\section{TRANSMISSION BLOCKING P. vivax VACCINE CANDIDATES}

One of the methodologies used for controlling malaria infection has been the search for transmission blocking vaccines, through strategies for preventing ookinete development in the vector (234). The assays conducted for transmission blocking have been focused on two main proteins, Pvs 25 and Pvs28, expressed on gametocyte surface. Anti-sera have recognized $P v 25$ in zygotes and mature ookinetes, and $P v 28$ more in mature ookinetes (235).

Immunogenicity tested with recombinant proteins $P v s 25$ and Pvs28 in mice has shown a splenic T-cell proliferative response. Anti-sera from mice immunized with a $P v s 25-28$ chimera had a high antibody titer compared to mice immunized with $P v s 25$ or $P v s 28$ alone. Anti- $P v s 25-28$ and anti- $P v s 25$ had higher transmission blocking than anti-Pvs28 $(235,236)$.

Studies had demonstrated that $P$. vivax SalI strain recombinant $P v$ s 25 and $P v s 28$ had transmission blocking capability, even with natural isolates, thus overcoming genetic polymorphism between isolates (237). Higher transmission blocking has been described as a direct function of antibody titers in sera (238-240).

Different vaccination schemes have been tested, varying adjuvant, dose, expression system (148, 237, 238, 240, 241). Phase I clinical trials determining security and immunogenicity in humans have shown high transmission blocking capability in humans, demonstrating these antigens' potential as vaccine candidates $(147,148)$.

\section{CONCLUSION}

This review has summarized immune responses induced by $P$. vivax vaccine candidates, which are essential in host cell invasion. Classical vaccine development has been focused on immunodominant antigens such as sporozoite and MSPs, which are recognized by sera from partially protected individuals who are naturally exposed to infection. However, surface proteins, for example $P v \mathrm{MSP} 1$ and $P v \mathrm{CSP}$, have high allelic polymorphism $(164,242,243)$ and are under positive selection by the immune response. After several natural infections, many of these epitopes 
have shown an ability to generate a strong immune response in individuals without clinical symptoms, showing an association with IFN- $\gamma$ effector T-cell activation and generation of cytophilic antibody subclasses. Similar immune responses have been observed in animal models immunized with these polymorphic immunodominant antigens. Nevertheless, the success for this kind of vaccines has been limited, since the cross protectivity obtained for the remaining strains is very low and induces a short-lived immune response $(244,245)$. Moreover, parasites change their cell targets and molecules during preerythrocytic, erythrocytic, and sexual stages, and single-antigen/single-stage vaccines do not induce sterile protection. It has been observed that $P$. falciparum parasites hide their amino acid conserved domains of the proteins involved in the invasion of host cells, showing immune dominant and polymorphic epitopes to the immune system (246).

Other methodologies are needed to solve these kinds of issue. An alternative is to develop an antimalarial vaccine (246), focused on synthetic peptides designed on conserved regions of Spz and Mrz proteins having high hepatic cell or RBC-binding ability. Although these peptides are not immunogenic, $P$. falciparum and $P$. vivax studies have shown that such peptides can be modified by changing their critical RBC-binding residues for others having similar mass but opposite polarity, making them highly immunogenic and protective $(247,248)$.

Another problem in the development of an antimalarial vaccine concerns the many haplotypes present in the exposed population. The HABPs can also be modified that fit properly inside the peptide-binding region of MHCII. In studies with $P$. falciparum with a MSP-2 HABP that has been modified to bind to HLA-DR $\beta 1^{\star} 0403$ molecules with high affinity, it was shown that Aotus monkeys bearing HLA-DR $\beta 1^{\star} 0403$-like molecules,

\section{REFERENCES}

1. WHO. In: Press W, editor. World Malaria Report. (2015). p. 280.

2. Udomsangpetch R, Kaneko O, Chotivanich K, Sattabongkot J. Cultivation of Plasmodium vivax. Trends Parasitol (2008) 24(2):85-8. doi:10.1016/j. pt.2007.09.010

3. Mueller I, Galinski MR, Baird JK, Carlton JM, Kochar DK, Alonso PL, et al. Key gaps in the knowledge of Plasmodium vivax, a neglected human malaria parasite. Lancet Infect Dis (2009) 9(9):555-66. doi:10.1016/ S1473-3099(09)70177-X

4. Jiang N, Chang Q, Sun X, Lu H, Yin J, Zhang Z, et al. Co-infections with Plasmodium knowlesi and other malaria parasites, Myanmar. Emerg Infect Dis (2010) 16(9):1476-8. doi:10.3201/eid1609.100339

5. Nino CH, Cubides JR, Camargo-Ayala PA, Rodriguez-Celis CA, Quinones T, Cortes-Castillo MT, et al. Plasmodium malariae in the Colombian Amazon region: you don't diagnose what you don't suspect. Malar J (2016) 15(1):576. doi:10.1186/s12936-016-1629-3

6. Mayxay M, Pukrittayakamee S, Newton PN, White NJ. Mixed-species malaria infections in humans. Trends Parasitol (2004) 20(5):233-40. doi:10.1016/ j.pt.2004.03.006

7. Rieckmann K, Davis D, Hutton D. Plasmodium vivax resistance to chloroquine? Lancet (1989) 334(8673):1183-4. doi:10.1016/S0140-6736(89) 91792-3

8. Khatoon L, Baliraine FN, Bonizzoni M, Malik SA, Yan G. Prevalence of antimalarial drug resistance mutations in Plasmodium vivax and P. falciparum from a malaria-endemic area of Pakistan. Am J Trop Med Hyg (2009) 81(3):525-8. produced high antibody titers with sterile immunity after challenge with $P$. falciparum FVO. This was a proof-of-concept immune protection-inducing protein structures demonstrating that specifically modified HABPs are able to induce sterile protection against malaria by engaging the proper TCR/pMHCII interactions (249).

Evaluation of conserved epitopes and non-immunodominant antigens important in parasite adhesion and invasion of erythrocytes should be prioritized for multistage, multi-epitope, minimal subunit-based, chemically synthesized antimalarial development, covering a large part of the HLA-DR $\beta 1^{\star}$ population in endemic areas to protect them against malarial parasites.

\section{AUTHOR CONTRIBUTIONS}

CL conceived the work and drafted the manuscript; YY-P drafted the manuscript and designed the figures; $\mathrm{NH}$-E and DD-A drafted the manuscript; MP critically revised the manuscript for important intellectual content. All authors have revised the manuscript and given their approval for the version to be submitted.

\section{ACKNOWLEDGMENTS}

We would like to thank Jason Garry for translating and thoroughly revising the manuscript and Professor Manuel Elkin Patarroyo for his suggestions.

\section{FUNDING}

This work was financed by the Colombian Science, Technology and Innovation Department (COLCIENCIAS) through grant RC \# 0309-2013.

9. Price RN, von Seidlein L, Valecha N, Nosten F, Baird JK, White NJ. Global extent of chloroquine-resistant Plasmodium vivax: a systematic review and meta-analysis. Lancet Infect Dis (2014) 14(10):982-91. doi:10.1016/ S1473-3099(14)70855-2

10. Suwanarusk R, Chavchich M, Russell B, Jaidee A, Chalfein F, Barends M, et al. Amplification of pvmdr1 associated with multidrug-resistant Plasmodium vivax. J Infect Dis (2008) 198(10):1558-64. doi:10.1086/592451

11. Khim N, Andrianaranjaka V, Popovici J, Kim S, Ratsimbasoa A, Benedet C, et al. Effects of mefloquine use on Plasmodium vivax multidrug resistance. Emerg Infect Dis (2014) 20(10):1637-44. doi:10.3201/eid2010.140411

12. Prakash J, Singh A, Kumar N, Saxena R. Acute renal failure in Plasmodium vivax malaria. J Assoc Physicians India (2003) 51:265-7.

13. Nautiyal A, Singh S, Parameswaran G, DiSalle M. Hepatic dysfunction in a patient with Plasmodium vivax infection. Medsc Gen Med (2005) 7(1):8.

14. Tjitra E, Anstey NM, Sugiarto P, Warikar N, Kenangalem E, Karyana M, et al. Multidrug-resistant Plasmodium vivax associated with severe and fatal malaria: a prospective study in Papua, Indonesia. PLoS Med (2008) 5(6):e128. doi:10.1371/journal.pmed.0050128

15. Naha K, Dasari S, Prabhu M. Spectrum of complications associated with Plasmodium vivax infection in a tertiary hospital in South-Western India. Asian PacJ Trop Med (2012) 5(1):79-82. doi:10.1016/S1995-7645(11)60251-4

16. Rizvi I, Tripathi DK, Chughtai AM, Beg M, Zaman S, Zaidi N. Complications associated with Plasmodium vivax malaria: a retrospective study from a tertiary care hospital based in Western Uttar Pradesh, India. Ann Afr Med (2013) 12(3):155. doi:10.4103/1596-3519.117624

17. Kumar R, Agarwal D, Kumar P. Severe Plasmodium vivax malaria in children: an emerging threat. J Pediatr Sci (2014) 6:e210. doi:10.17334/jps.99493 
18. Price RN, Tjitra E, Guerra CA, Yeung S, White NJ, Anstey NM. Vivax malaria: neglected and not benign. Am J Trop Med Hyg (2007) 77(6 Suppl): 79-87.

19. Guerra CA, Howes RE, Patil AP, Gething PW, Van Boeckel TP, Temperley $\mathrm{WH}$, et al. The international limits and population at risk of Plasmodium vivax transmission in 2009. PLoS Negl Trop Dis (2010) 4(8):e774. doi:10.1371/ journal.pntd.0000774

20. White NJ. Determinants of relapse periodicity in Plasmodium vivax malaria. Malar J (2011) 10(1):1. doi:10.1186/1475-2875-10-297

21. Sinnis P, Coppi A. A long and winding road: the Plasmodium sporozoite's journey in the mammalian host. Parasitol Int (2007) 56(3):171-8. doi:10.1016/ j.parint.2007.04.002

22. Gueirard P, Tavares J, Thiberge S, Bernex F, Ishino T, Milon G, et al. Development of the malaria parasite in the skin of the mammalian host. Proc Natl Acad Sci U S A (2010) 107(43):18640-5. doi:10.1073/pnas.1009346107

23. Amino R, Thiberge S, Martin B, Celli S, Shorte S, Frischknecht F, et al. Quantitative imaging of Plasmodium transmission from mosquito to mammal. Nat Med (2006) 12(2):220-4. doi:10.1038/nm1350

24. Vaughan AM, Aly AS, Kappe SH. Malaria parasite pre-erythrocytic stage infection: gliding and hiding. Cell Host Microbe (2008) 4(3):209-18. doi:10.1016/j.chom.2008.08.010

25. Menard R, Tavares J, Cockburn I, Markus M, Zavala F, Amino R. Looking under the skin: the first steps in malarial infection and immunity. Nat Rev Microbiol (2013) 11(10):701-12. doi:10.1038/nrmicro3111

26. Good MF, Doolan DL. Malaria vaccine design: immunological considerations. Immunity (2010) 33(4):555-66. doi:10.1016/j.immuni.2010.10.005

27. Duffy PE, Sahu T, Akue A, Milman N, Anderson C. Pre-erythrocytic malaria vaccines: identifying the targets. Expert Rev Vaccines (2012) 11(10):1261-80. doi:10.1586/erv.12.92

28. Schofield L, Grau GE. Immunological processes in malaria pathogenesis. Nat Rev Immunol (2005) 5(9):722-35. doi:10.1038/nri1686

29. Hiller NL, Bhattacharjee S, van Ooij C, Liolios K, Harrison T, Lopez-Estrano $\mathrm{C}$, et al. A host-targeting signal in virulence proteins reveals a secretome in malarial infection. Science (2004) 306(5703):1934-7. doi:10.1126/ science. 1102737

30. Marti M, Good RT, Rug M, Knuepfer E, Cowman AF. Targeting malaria virulence and remodeling proteins to the host erythrocyte. Science (2004) 306(5703):1930-3. doi:10.1126/science.1102452

31. Singh AP, Buscaglia CA, Wang Q, Levay A, Nussenzweig DR, Walker JR, et al. Plasmodium circumsporozoite protein promotes the development of the liver stages of the parasite. Cell (2007) 131(3):492-504. doi:10.1016/ j.cell.2007.09.013

32. Aggarwal BB. Nuclear factor-kappaB: the enemy within. Cancer Cell (2004) 6(3):203-8. doi:10.1016/j.ccr.2004.09.003

33. Baer K, Klotz C, Kappe SH, Schnieder T, Frevert U. Release of hepatic Plasmodium yoelii merozoites into the pulmonary microvasculature. PLoS Pathog (2007) 3(11):e171. doi:10.1371/journal.ppat.0030171

34. Baird JK, Jones TR, Danudirgo EW, Annis BA, Bangs MJ, Basri H, et al. Agedependent acquired protection against Plasmodium falciparum in people having two years exposure to hyperendemic malaria. Am J Trop Med Hyg (1991) 45(1):65-76.

35. Christophers SR. The mechanism of immunity against malaria in communities living under hyper-endemic conditions. Indian J Med Res (1924) 12(2):273-94.

36. Brown $\mathrm{KN}$, Brown IN. Immunity to malaria: antigenic variation in chronic infections of Plasmodium knowlesi. Nature (1965) 208(5017):1286-8. doi:10.1038/2081286a0

37. Pérignon JL, Druilhe P. Immune mechanisms underlying the premunition against Plasmodium falciparum malaria. Mem Inst Oswaldo Cruz (1994) 89:51-3. doi:10.1590/S0074-02761994000600013

38. Doolan DL, Dobaño C, Baird JK. Acquired immunity to malaria. Clin Microbiol Rev (2009) 22(1):13-36. doi:10.1128/CMR.00025-08

39. Snounou G, Pérignon J-L. Malariotherapy-insanity at the service of malariology. Adv Parasitol (2013) 81(6):223-55. doi:10.1016/ B978-0-12-407826-0.00006-0

40. Yamauchi LM, Coppi A, Snounou G, Sinnis P. Plasmodium sporozoites trickle out of the injection site. Cell Microbiol (2007) 9(5):1215-22. doi:10.1111/j.1462-5822.2006.00861.x
41. Amorim KN, Chagas DC, Sulczewski FB, Boscardin SB. Dendritic cells and their multiple roles during malaria infection. J Immunol Res (2016) 2016:2926436. doi:10.1155/2016/2926436

42. Gazzinelli RT, Kalantari P, Fitzgerald KA, Golenbock DT. Innate sensing of malaria parasites. Nat Rev Immunol (2014) 14(11):744-57. doi:10.1038/ nri3742

43. Jani D, Nagarkatti R, Beatty W, Angel R, Slebodnick C, Andersen J, et al. HDP-a novel heme detoxification protein from the malaria parasite. PLoS Pathog (2008) 4(4):e1000053. doi:10.1371/journal.ppat.1000053

44. Parroche P, Lauw FN, Goutagny N, Latz E, Monks BG, Visintin A, et al. Malaria hemozoin is immunologically inert but radically enhances innate responses by presenting malaria DNA to toll-like receptor 9. Proc Natl Acad Sci U S A (2007) 104(6):1919-24. doi:10.1073/pnas.0608745104

45. Coban C, Igari Y, Yagi M, Reimer T, Koyama S, Aoshi T, et al. Immunogenicity of whole-parasite vaccines against Plasmodium falciparum involves malarial hemozoin and host TLR9. Cell Host Microbe (2010) 7(1):50-61. doi:10.1016/ j.chom.2009.12.003

46. Ghosh D, Stumhofer JS. Do you see what I see: recognition of protozoan parasites by toll-like receptors. Curr Immunol Rev (2013) 9(3):129-40. doi:10.2174/1573395509666131203225929

47. Sharma S, DeOliveira RB, Kalantari P, Parroche P, Goutagny N, Jiang Z, et al. Innate immune recognition of an AT-rich stem-loop DNA motif in the Plasmodium falciparum genome. Immunity (2011) 35(2):194-207. doi:10.1016/j.immuni.2011.05.016

48. Schofield L, Hackett F. Signal transduction in host cells by a glycosylphosphatidylinositol toxin of malaria parasites. J Exp Med (1993) 177(1):145-53. doi:10.1084/jem.177.1.145

49. Krishnegowda G, Hajjar AM, Zhu J, Douglass EJ, Uematsu S, Akira S, et al. Induction of proinflammatory responses in macrophages by the glycosylphosphatidylinositols of Plasmodium falciparum: cell signaling receptors, glycosylphosphatidylinositol (GPI) structural requirement, and regulation of GPI activity. J Biol Chem (2005) 280(9):8606-16. doi:10.1074/ jbc.M413541200

50. Gazzinelli RT, Denkers EY. Protozoan encounters with toll-like receptor signalling pathways: implications for host parasitism. Nat Rev Immunol (2006) 6(12):895-906. doi:10.1038/nri1978

51. Durai P, Govindaraj RG, Choi S. Structure and dynamic behavior of Toll-like receptor 2 subfamily triggered by malarial glycosylphosphatidylinositols of Plasmodium falciparum. FEBS J (2013) 280(23):6196-212. doi:10.1111/ febs. 12541

52. Wykes MN, Good MF. What really happens to dendritic cells during malaria? Nat Rev Microbiol (2008) 6(11):864-70. doi:10.1038/nrmicro1988

53. Skorokhod OA, Alessio M, Mordmuller B, Arese P, Schwarzer E. Hemozoin (malarial pigment) inhibits differentiation and maturation of human monocyte-derived dendritic cells: a peroxisome proliferator-activated receptor-gamma-mediated effect. J Immunol (2004) 173(6):4066-74. doi:10.4049/ jimmunol.173.6.4066

54. Elliott SR, Spurck TP, Dodin JM, Maier AG, Voss TS, Yosaatmadja F, et al. Inhibition of dendritic cell maturation by malaria is dose dependent and does not require Plasmodium falciparum erythrocyte membrane protein 1. Infect Immun (2007) 75(7):3621-32. doi:10.1128/IAI.00095-07

55. Stern LJ, Calvo-Calle JM. HLA-DR: molecular insights and vaccine design. Curr Pharm Des (2009) 15(28):3249-61. doi:10.2174/138161209789105171

56. Lima-Junior Jda C, Pratt-Riccio LR. Major histocompatibility complex and malaria: focus on Plasmodium vivax infection. Front Immunol (2016) 7:13. doi:10.3389/fimmu.2016.00013

57. Riley EM, Stewart VA. Immune mechanisms in malaria: new insights in vaccine development. Nat Med (2013) 19(2):168-78. doi:10.1038/nm.3083

58. Praba-Egge AD, Montenegro S, Arevalo-Herrera M, Hopper T, Herrera S, James MA. Human cytokine responses to meso-endemic malaria on the Pacific Coast of Colombia. Ann Trop Med Parasitol (2003) 97(4):327-37. doi:10.1179/000349803235002399

59. Hemmer CJ, Holst FG, Kern P, Chiwakata CB, Dietrich M, Reisinger EC. Stronger host response per parasitized erythrocyte in Plasmodium vivax or ovale than in Plasmodium falciparum malaria. Trop Med Int Health (2006) 11(6):817-23. doi:10.1111/j.1365-3156.2006.01635.x

60. Alifrangis M, Lemnge MM, Moon R, Theisen M, Bygbjerg I, Ridley RG, et al. IgG reactivities against recombinant rhoptry-associated protein-1 
(rRAP-1) are associated with mixed Plasmodium infections and protection against disease in Tanzanian children. Parasitology (1999) 119(Pt 4):337-42. doi:10.1017/S0031182099004825

61. Maitland K, Williams TN, Newbold CI. Plasmodium vevax and P. falciparum: biological interactions and the possibility of cross-species immunity. Parasitol Today (1997) 13(6):227-31. doi:10.1016/S0169-4758(97)01061-2

62. Smith T, Genton B, Baea K, Gibson N, Narara A, Alpers MP. Prospective risk of morbidity in relation to malaria infection in an area of high endemicity of multiple species of Plasmodium. Am J Trop Med Hyg (2001) 64(5-6):262-7.

63. Andrade BB, Reis-Filho A, Souza-Neto SM, Clarencio J, Camargo LM, Barral A, et al. Severe Plasmodium vivax malaria exhibits marked inflammatory imbalance. Malar J (2010) 9:13. doi:10.1186/1475-2875-9-13

64. Langhorne J, Ndungu FM, Sponaas AM, Marsh K. Immunity to malaria: more questions than answers. Nat Immunol (2008) 9(7):725-32. doi:10.1038/ ni.f. 205

65. Medina TS, Costa SP, Oliveira MD, Ventura AM, Souza JM, Gomes TF, et al. Increased interleukin-10 and interferon-gamma levels in Plasmodium vivax malaria suggest a reciprocal regulation which is not altered by IL-10 gene promoter polymorphism. Malar J (2011) 10:264. doi:10.1186/1475-2875$10-264$

66. Goncalves RM, Scopel KK, Bastos MS, Ferreira MU. Cytokine balance in human malaria: does Plasmodium vivax elicit more inflammatory responses than Plasmodium falciparum? PLoS One (2012) 7(9):e44394. doi:10.1371/ journal.pone.0044394

67. Mendonça VR, Queiroz AT, Lopes FM, Andrade BB, Barral-Netto M. Networking the host immune response in Plasmodium vivax malaria. Malar $J(2013)$ 12(1):1. doi:10.1186/1475-2875-12-69

68. Mendonca VR, Andrade BB, Souza LC, Magalhaes BM, Mourao MP, Lacerda $\mathrm{MV}$, et al. Unravelling the patterns of host immune responses in Plasmodium vivax malaria and dengue co-infection. Malar J (2015) 14:315. doi:10.1186/ s12936-015-0835-8

69. Cohen S, Mc GI, Carrington S. Gamma-globulin and acquired immunity to human malaria. Nature (1961) 192:733-7. doi:10.1038/192733a0

70. Sabchareon A, Burnouf T, Ouattara D, Attanath P, Bouharoun-Tayoun H, Chantavanich $\mathrm{P}$, et al. Parasitologic and clinical human response to immunoglobulin administration in falciparum malaria. Am J Trop Med Hyg (1991) 45(3):297-308.

71. Gysin J, Moisson P, Pereira da Silva L, Druilhe P. Antibodies from immune African donors with a protective effect in Plasmodium falciparum human infection are also able to control asexual blood forms of the parasite in Saimiri monkeys. Res Immunol (1996) 147(6):397-401. doi:10.1016/0923-2494(96)82048-7

72. Hollingdale MR, Nardin EH, Tharavanij S, Schwartz AL, Nussenzweig RS. Inhibition of entry of Plasmodium falciparum and $P$. vivax sporozoites into cultured cells; an in vitro assay of protective antibodies. J Immunol (1984) 132(2):909-13.

73. Nardin E, Zavala F, Nussenzweig V, Nussenzweig RS. Pre-erythrocytic malaria vaccine: mechanisms of protective immunity and human vaccine trials. Parassitologia (1999) 41(1-3):397-402.

74. Rathore D, Nagarkatti R, Jani D, Chattopadhyay R, de la Vega P, Kumar S, et al. An immunologically cryptic epitope of Plasmodium falciparum circumsporozoite protein facilitates liver cell recognition and induces protective antibodies that block liver cell invasion. J Biol Chem (2005) 280(21):20524-9. doi:10.1074/jbc.M414254200

75. Bouharoun-Tayoun H, Attanath P, Sabchareon A, Chongsuphajaisiddhi T, Druilhe P. Antibodies that protect humans against Plasmodium falciparum blood stages do not on their own inhibit parasite growth and invasion in vitro, but act in cooperation with monocytes. J Exp Med (1990) 172(6):1633-41. doi:10.1084/jem.172.6.1633

76. Bouharoun-Tayoun H, Oeuvray C, Lunel F, Druilhe P. Mechanisms underlying the monocyte-mediated antibody-dependent killing of Plasmodium falciparum asexual blood stages. J Exp Med (1995) 182(2):409-18. doi:10.1084/ jem.182.2.409

77. Arévalo-Herrera M, Soto L, Perlaza BL, Céspedes N, Vera O, Lenis AM, et al. Antibody-mediated and cellular immune responses induced in naive volunteers by vaccination with long synthetic peptides derived from the Plasmodium vivax circumsporozoite protein. Am J Trop Med Hyg (2011) 84(2 Suppl):35-42. doi:10.4269/ajtmh.2011.09-0507
78. Soares IS, Levitus G, Souza JM, Del Portillo HA, Rodrigues MM. Acquired immune responses to the $\mathrm{N}$-and $\mathrm{C}$-terminal regions of Plasmodium vivax merozoite surface protein 1 in individuals exposed to malaria. Infect Immun (1997) 65(5):1606-14.

79. Nogueira PA, Alves FP, Fernandez-Becerra C, Pein O, Santos NR, da Silva LHP, et al. A reduced risk of infection with Plasmodium vivax and clinical protection against malaria are associated with antibodies against the $\mathrm{N}$ terminus but not the $\mathrm{C}$ terminus of merozoite surface protein 1. Infect Immun (2006) 74(5):2726-33. doi:10.1128/IAI.74.5.2726-2733.2006

80. Versiani FG, Almeida ME, Melo GC, Versiani FO, Orlandi PP, Mariuba LA, et al. High levels of IgG3 anti ICB2-5 in Plasmodium vivax-infected individuals who did not develop symptoms. Malar J (2013) 12:294. doi:10.1186/1475-2875-12-294

81. Cheng Y, Shin E-H, Lu F, Wang B, Choe J, Tsuboi T, et al. Antigenicity studies in humans and immunogenicity studies in mice: an MSP1P subdomain as a candidate for malaria vaccine development. Microb Infect (2014) 16(5):419-28. doi:10.1016/j.micinf.2014.02.002

82. Tran TM, Oliveira-Ferreira J, Moreno A, Santos F, Yazdani SS, Chitnis CE, et al. Comparison of IgG reactivities to Plasmodium vivax merozoite invasion antigens in a Brazilian Amazon population. Am J Trop Med Hyg (2005) 73(2):244-55.

83. Ferreira AR, Singh B, Cabrera-Mora M, De Souza ACM, Marques MTQ, Porto LCS, et al. Evaluation of naturally acquired IgG antibodies to a chimeric and non-chimeric recombinant species of Plasmodium vivax reticulocyte binding protein-1: lack of association with HLA-DRB1 ${ }^{*} / \mathrm{DQB1}^{*}$ in malaria exposed individuals from the Brazilian Amazon. PLoS One (2014) 9(8):e105828. doi:10.1371/journal.pone.0105828

84. Yildiz Zeyrek F, Palacpac N, Yuksel F, Yagi M, Honjo K, Fujita Y, et al. Serologic markers in relation to parasite exposure history help to estimate transmission dynamics of Plasmodium vivax. PLoS One (2011) 6(11):e28126. doi:10.1371/journal.pone.0028126

85. Lima-Junior JC, Jiang J, Rodrigues-da-Silva R, Banic D, Tran T, Ribeiro $\mathrm{R}$, et al. B cell epitope mapping and characterization of naturally acquired antibodies to the Plasmodium vivax merozoite surface protein-3 $\alpha$ (PvMSP$3 \alpha$ ) in malaria exposed individuals from Brazilian Amazon. Vaccine (2011) 29(9):1801-11. doi:10.1016/j.vaccine.2010.12.099

86. Lima-Junior JC, Rodrigues-da-Silva RN, Banic DM, Jiang J, Singh B, Fabricio-Silva GM, et al. Influence of HLA-DRB1 and HLA-DQB1 alleles on IgG antibody response to the P. vivax MSP-1, MSP-3 $\alpha$ and MSP-9 in individuals from Brazilian endemic area. PLoS One (2012) 7(5):e36419. doi:10.1371/ journal.pone.0036419

87. Herrera S, Bonelo A, Perlaza BL, Valencia AZ, Cifuentes C, Hurtado S, et al. Use of long synthetic peptides to study the antigenicity and immunogenicity of the Plasmodium vivax circumsporozoite protein. Int J Parasitol (2004) 34(13):1535-46. doi:10.1016/j.ijpara.2004.10.009

88. Céspedes N, Arévalo-Herrera M, Felger I, Reed S, Kajava AV, Corradin $\mathrm{G}$, et al. Antigenicity and immunogenicity of a novel chimeric peptide antigen based on the P. vivax circumsporozoite protein. Vaccine (2013) 31(42):4923-30. doi:10.1016/j.vaccine.2013.05.082

89. Agnandji ST, Lell B, Fernandes JF, Abossolo BP, Methogo B, Kabwende AL, et al. A phase 3 trial of RTS, S/AS01 malaria vaccine in African infants. N Engl J Med (2012) 367(24):2284-95. doi:10.1056/NEJMoa1208394

90. Lumsden JM, Pichyangkul S, Srichairatanakul U, Yongvanitchit K, Limsalakpetch A, Nurmukhambetova S, et al. Evaluation of the safety and immunogenicity in rhesus monkeys of a recombinant malaria vaccine for Plasmodium vivax with a synthetic toll-like receptor 4 agonist formulated in an emulsion. Infect Immun (2011) 79(9):3492-500. doi:10.1128/ IAI.05257-11

91. Rui E, Fernandez-Becerra C, Takeo S, Sanz S, Lacerda MV, Tsuboi T, et al. Plasmodium vivax: comparison of immunogenicity among proteins expressed in the cell-free systems of Escherichia coli and wheat germ by suspension array assays. Malar J (2011) 10(1):1. doi:10.1186/1475-2875-10-192

92. Neafsey DE, Juraska M, Bedford T, Benkeser D, Valim C, Griggs A, et al. Genetic diversity and protective efficacy of the RTS, S/AS01 malaria vaccine. N Engl J Med (2015) 373(21):2025-37. doi:10.1056/NEJMoa1505819

93. Park J-W, Moon S-H, Yeom J-S, Lim K-J, Sohn M-J, Jung W-C, et al. Naturally acquired antibody responses to the C-terminal region of merozoite surface protein 1 of Plasmodium vivax in Korea. Clin Diagn Lab Immunol (2001) 8(1):14-20. doi:10.1128/CDLI.8.1.14-20.2001 
94. Valderrama-Aguirre A, Quintero G, Gomez A, Castellanos A, Perez Y, Mendez F, et al. Antigenicity, immunogenicity, and protective efficacy of Plasmodium vivax MSP1 PV2001: a potential malaria vaccine subunit. Am J Trop Med Hyg (2005) 73(5 Suppl):16-24.

95. Zeyrek FY, Babaoglu A, Demirel S, Erdogan DD, Ak M, Korkmaz M, et al. Analysis of naturally acquired antibody responses to the 19-kd C-terminal region of merozoite surface protein-1 of Plasmodium vivax from individuals in Sanliurfa, Turkey. Am J Trop Med Hyg (2008) 78(5):729-32.

96. Stanisic DI, Javati S, Kiniboro B, Lin E, Jiang J, Singh B, et al. Naturally acquired immune responses to $P$. vivax merozoite surface protein $3 \alpha$ and merozoite surface protein 9 are associated with reduced risk of $P$. vivax malaria in young Papua New Guinean children. PLoS Negl Trop Dis (2013) 7(11):e2498. doi:10.1371/journal.pntd.0002498

97. Bitencourt AR, Vicentin EC, Jimenez MC, Ricci R, Leite JA, Costa FT, et al. Antigenicity and immunogenicity of Plasmodium vivax merozoite surface protein-3. PLoS One (2013) 8(2):e56061. doi:10.1371/journal.pone.0056061

98. Lima-Junior JC, Tran TM, Meyer EV, Singh B, De-Simone SG, Santos F, et al. Naturally acquired humoral and cellular immune responses to Plasmodium vivax merozoite surface protein 9 in Northwestern Amazon individuals. Vaccine (2008) 26(51):6645-54. doi:10.1016/j.vaccine.2008.09.029

99. Lima-Junior JC, Banic DM, Tran TM, Meyer VS, De-Simone SG, Santos F, et al. Promiscuous T-cell epitopes of Plasmodium merozoite surface protein 9 (PvMSP9) induces IFN-gamma and IL-4 responses in individuals naturally exposed to malaria in the Brazilian Amazon. Vaccine (2010) 28(18):3185-91. doi:10.1016/j.vaccine.2010.02.046

100. Fraser T, Michon P, Barnwell JW, Noe AR, Al-Yaman F, Kaslow DC, et al. Expression and serologic activity of a soluble recombinant Plasmodium vivax Duffy binding protein. Infect Immun (1997) 65(7):2772-7.

101. Michon PA, Arevalo-Herrera M, Fraser T, Herrera S, Adams JH. Serologic responses to recombinant Plasmodium vivax Duffy binding protein in a Colombian village. Am J Trop Med Hyg (1998) 59(4):597-9.

102. Rodrigues MHC, Rodrigues KM, Oliveira TR, Cômodo AN, Rodrigues $\mathrm{MM}$, Kocken $\mathrm{CH}$, et al. Antibody response of naturally infected individuals to recombinant Plasmodium vivax apical membrane antigen-1. Int J Parasitol (2005) 35(2):185-92. doi:10.1016/j.ijpara.2004.11.003

103. Múfalo BC, Gentil F, Bargieri DY, Costa FT, Rodrigues MM, Soares IS. Plasmodium vivax apical membrane antigen-1: comparative recognition of different domains by antibodies induced during natural human infection. Microbes Infect (2008) 10(12):1266-73. doi:10.1016/j.micinf.2008.07.023

104. Haghi AM, Khoramizade MR, Nateghpour M, Mohebali M, Edrissian GH, Eshraghian MR, et al. A recombinant Plasmodium vivax apical membrane antigen-1 to detect human infection in Iran. Korean J Parasitol (2012) 50(1):15-21. doi:10.3347/kjp.2012.50.1.15

105. Cunha MG, Silva ES, Sepúlveda N, Costa SP, Saboia TC, Guerreiro JF, et al. Serologically defined variations in malaria endemicity in Pará state, Brazil. PLoS One (2014) 9(11):e113357. doi:10.1371/journal.pone.0113357

106. Tomaz FMMB, da Cruz Furini AA, Capobianco MP, Póvoa MM, Trindade PCA, Fraga VD, et al. Humoral immune responses against the malaria vaccine candidate antigen Plasmodium vivax AMA-1 and IL-4 gene polymorphisms in individuals living in an endemic area of the Brazilian Amazon. Cytokine (2015) 74(2):273-8. doi:10.1016/j.cyto.2015.03.020

107. Han J-H, Li J, Wang B, Lee S-K, Nyunt MH, Na S, et al. Identification of immunodominant B-cell epitope regions of reticulocyte binding proteins in Plasmodium vivax by protein microarray based immunoscreening. Korean J Parasitol (2015) 53(4):403. doi:10.3347/kjp.2015.53.4.403

108. Han J-H, Lee S-K, Wang B, Muh F, Nyunt MH, Na S, et al. Identification of a reticulocyte-specific binding domain of Plasmodium vivax reticulocyte-binding protein 1 that is homologous to the PfRh4 erythrocyte-binding domain. Sci Rep (2016) 6:26993. doi:10.1038/srep26993

109. Neefjes J, Jongsma ML, Paul P, Bakke O. Towards a systems understanding of MHC class I and MHC class II antigen presentation. Nat Rev Immunol (2011) 11(12):823-36. doi:10.1038/nri3084

110. Ujvari B, Belov K. Major histocompatibility complex (MHC) markers in conservation biology. Int J Mol Sci (2011) 12(8):5168-86. doi:10.3390/ ijms 12085168

111. Mazza C, Malissen B. What guides MHC-restricted TCR recognition? Semin Immunol (2007) 19(4):225-35. doi:10.1016/j.smim.2007.03.003

112. Oliveira-Ferreira J, Pratt-Riccio LR, Arruda M, Santos F, Ribeiro CT, Goldberg AC, et al. HLA class II and antibody responses to circumsporozoite protein repeats of $P$. vivax (VK210, VK247 and $P$. vivax-like) in individuals naturally exposed to malaria. Acta Trop (2004) 92(1):63-9. doi:10.1016/ j.actatropica.2004.02.011

113. Storti-Melo LM, da Costa DR, Souza-Neiras WC, Cassiano GC, Couto VS, Povoa MM, et al. Influence of HLA-DRB-1 alleles on the production of antibody against CSP, MSP-1, AMA-1, and DBP in Brazilian individuals naturally infected with Plasmodium vivax. Acta Trop (2012) 121(2):152-5. doi:10.1016/j.actatropica.2011.10.009

114. Miller LH, Mason SJ, Clyde DF, McGinniss MH. The resistance factor to Plasmodium vivax in blacks. The Duffy-blood-group genotype, FyFy. N Engl J Med (1976) 295(6):302-4. doi:10.1056/NEJM197608052950602

115. Michon P, Woolley I, Wood EM, Kastens W, Zimmerman PA, Adams JH. Duffy-null promoter heterozygosity reduces DARC expression and abrogates adhesion of the $P$. vivax ligand required for blood-stage infection. FEBS Lett (2001) 495(1-2):111-4. doi:10.1016/S0014-5793(01) 02370-5

116. Iwamoto S, Li J, Sugimoto N, Okuda H, Kajii E. Characterization of the Duffy gene promoter: evidence for tissue-specific abolishment of expression in Fy(a-b-) of black individuals. Biochem Biophys Res Commun (1996) 222(3):852-9. doi:10.1006/bbrc.1996.0833

117. Hamblin MT, Di Rienzo A. Detection of the signature of natural selection in humans: evidence from the Duffy blood group locus. Am J Hum Genet (2000) 66(5):1669-79. doi:10.1086/302879

118. Tournamille C, Colin Y, Cartron JP, Le Van Kim C. Disruption of a GATA motif in the Duffy gene promoter abolishes erythroid gene expression in Duffy-negative individuals. Nat Genet (1995) 10(2):224-8. doi:10.1038/ ng0695-224

119. Lopez C, Saravia C, Gomez A, Hoebeke J, Patarroyo MA. Mechanisms of genetically-based resistance to malaria. Gene (2010) 467(1-2):1-12. doi:10.1016/j.gene.2010.07.008

120. Woldearegai TG, Kremsner PG, Kun JF, Mordmuller B. Plasmodium vivax malaria in Duffy-negative individuals from Ethiopia. Trans $R$ Soc Trop Med Hyg (2013) 107(5):328-31. doi:10.1093/trstmh/trt016

121. Mendes C, Dias F, Figueiredo J, Mora VG, Cano J, de Sousa B, et al. Duffy negative antigen is no longer a barrier to Plasmodium vivax - molecular evidences from the African West Coast (Angola and Equatorial Guinea). PLoS Negl Trop Dis (2011) 5(6):e1192. doi:10.1371/journal.pntd.0001192

122. Sohail M, Kaul A, Bali P, Raziuddin M, Singh MP, Singh OP, et al. Alleles $-308 \mathrm{~A}$ and $-1031 \mathrm{C}$ in the TNF-alpha gene promoter do not increase the risk but associated with circulating levels of TNF-alpha and clinical features of vivax malaria in Indian patients. Mol Immunol (2008) 45(6):1682-92. doi:10.1016/j.molimm.2007.10.002

123. Sortica VA, Cunha MG, Ohnishi MD, Souza JM, Ribeiro-Dos-Santos AK, Santos NP, et al. IL1B, IL4R, IL12RB1 and TNF gene polymorphisms are associated with Plasmodium vivax malaria in Brazil. Malar J (2012) 11:409. doi:10.1186/1475-2875-11-409

124. da Silva Santos S, Clark TG, Campino S, Suarez-Mutis MC, Rockett KA, Kwiatkowski DP, et al. Investigation of host candidate malaria-associated risk/protective SNPs in a Brazilian Amazonian population. PLoS One (2012) 7(5):e36692. doi:10.1371/journal.pone.0036692

125. Mendonça VR, Souza LC, Garcia GC, Magalhães BM, Lacerda MV, Andrade BB, et al. DDX39B (BAT1), TNF and IL6 gene polymorphisms and association with clinical outcomes of patients with Plasmodium vivax malaria. Malar $J$ (2014) 13(1):1. doi:10.1186/1475-2875-13-278

126. Aldrich C, Magini A, Emiliani C, Dottorini T, Bistoni F, Crisanti A, et al. Roles of the amino terminal region and repeat region of the Plasmodium berghei circumsporozoite protein in parasite infectivity. PLoS One (2012) 7(2):e32524. doi:10.1371/journal.pone.0032524

127. Persson C, Oliveira GA, Sultan AA, Bhanot P, Nussenzweig V, Nardin E. Cutting edge: a new tool to evaluate human pre-erythrocytic malaria vaccines: rodent parasites bearing a hybrid Plasmodium falciparum circumsporozoite protein. JImmunol (2002) 169(12):6681-5. doi:10.4049/ jimmunol.169.12.6681

128. Céspedes N, Jiménez E, Lopez-Perez M, Rubiano K, Felger I, Alonso P, et al. Antigenicity and immunogenicity of a novel Plasmodium vivax circumsporozoite derived synthetic vaccine construct. Vaccine (2014) 32(26):3179-86. doi:10.1016/j.vaccine.2014.04.007

129. Rathore D, Sacci JB, de la Vega P, McCutchan TF. Binding and invasion of liver cells by Plasmodium falciparum sporozoites Essential involvement 
of the amino terminus of circumsporozoite protein. J Biol Chem (2002) 277(9):7092-8. doi:10.1074/jbc.M106862200

130. Nussenzweig V, Nussenzweig RS. Rationale for the development of an engineered sporozoite malaria vaccine. Adv Immunol (1989) 45:283-334. doi:10.1016/S0065-2776(08)60695-1

131. White MT, Verity R, Griffin JT, Asante KP, Owusu-Agyei S, Greenwood B, et al. Immunogenicity of the RTS, S/AS01 malaria vaccine and implications for duration of vaccine efficacy: secondary analysis of data from a phase 3 randomised controlled trial. Lancet Infect Dis (2015) 15(12):1450-8. doi:10.1016/S1473-3099(15)00239-X

132. Olotu A, Fegan G, Wambua J, Nyangweso G, Leach A, Lievens M, et al. Seven-year efficacy of RTS,S/AS01 malaria vaccine among young African children. N Engl J Med (2016) 374(26):2519-29. doi:10.1056/ NEJMoa1515257

133. Rts SCTP. Efficacy and safety of RTS,S/AS01 malaria vaccine with or without a booster dose in infants and children in Africa: final results of a phase 3, individually randomised, controlled trial. Lancet (2015) 386(9988):31-45. doi:10.1016/S0140-6736(15)60721-8

134. Zavala F, Tam JP, Barr PJ, Romero P, Ley V, Nussenzweig RS, et al. Synthetic peptide vaccine confers protection against murine malaria. J Exp Med (1987) 166(5):1591-6. doi:10.1084/jem.166.5.1591

135. Weiss WR, Berzofsky J, Houghten RA, Sedegah M, Hollindale M, Hoffman SL. AT cell clone directed at the circumsporozoite protein which protects mice against both Plasmodium yoelii and Plasmodium berghei. J Immunol (1992) 149(6):2103-9.

136. Marussig M, Rénia L, Motard A, Miltgen F, Pétour P, Chauhan V, et al. Linear and multiple antigen peptides containing defined $\mathrm{T}$ and $\mathrm{B}$ epitopes of the Plasmodium yoelii circumsporozoite protein: antibody-mediated protection and boosting by sporozoite infection. Int Immunol (1997) 9(12):1817-24. doi:10.1093/intimm/9.12.1817

137. Doolan DL, Hoffman SL. IL-12 and NK cells are required for antigen-specific adaptive immunity against malaria initiated by $\mathrm{CD} 8+\mathrm{T}$ cells in the Plasmodium yoelii model. J Immunol (1999) 163(2):884-92.

138. Rosenberg R, Wirtz RA, Lanar DE, Sattabongkot J, Hall T, Waters AP, et al. Circumsporozoite protein heterogeneity in the human malaria parasite Plasmodium vivax. Science (1989) 245(4921):973-6. doi:10.1126/ science. 2672336

139. Qari SH, Shi V-P, Povoa MM, Alpers MP, Deloron P, Murphy GS, et al. Global occurrence of Plasmodium vivax-like human malaria parasite. J Infect Dis (1993) 168(6):1485-9. doi:10.1093/infdis/168.6.1485

140. Machado RL, Póvoa MM. Distribution of Plasmodium vivax variants (VK210, VK247 and P. vivax-like) in three endemic areas of the Amazon region of Brazil and their correlation with chloroquine treatment. Trans $R$ Soc Trop Med Hyg (2000) 94(4):377-81. doi:10.1016/S0035-9203(00)90110-X

141. Cochrane AH, Nardin EH, De Arruda M, Maracic M, Clavijo P, Collins $\mathrm{WE}$, et al. Widespread reactivity of human sera with a variant repeat of the circumsporozoite protein of Plasmodium vivax. Am J Trop Med Hyg (1990) 43(5):446-51.

142. Wirtz R, Rosenberg R, Sattabongkot J, Webster H. Prevalence of antibody to heterologous circumsporozoite protein of Plasmodium vivax in Thailand. Lancet (1990) 336(8715):593-5. doi:10.1016/0140-6736(90)93393-4

143. Franke ED, Lucas CM, San Roman E, Wirtz RA. Prevalence of antibody to the variant repeat of the circumsporozoite protein of Plasmodium vivax in Peru. Am J Trop Med Hyg (1992) 46(6):708-10.

144. Gonzalez J, Hurtado S, Arevalo-Herrera M, Herrera S. Variants of the Plasmodium vivax circumsporozoite protein (VK210 and VK247) in Colombian isolates. Mem Inst Oswaldo Cruz (2001) 96(5):709-12. doi:10.1590/S0074-02762001000500023

145. Herrera S, Fernández OL, Vera O, Cárdenas W, Ramírez O, Palacios R, et al. Phase I safety and immunogenicity trial of Plasmodium vivax CS derived long synthetic peptides adjuvanted with montanide ISA 720 or montanide ISA 51. Am J Trop Med Hyg (2011) 84(2 Suppl):12-20. doi:10.4269/ aitmh.2011.09-0516

146. Bennett JW, Yadava A, Tosh D, Sattabongkot J, Komisar J, Ware LA, et al. Phase 1/2a Trial of Plasmodium vivax malaria vaccine candidate VMP001/ AS01 B in malaria-naive adults: safety, immunogenicity, and efficacy. PLoS Negl Trop Dis (2016) 10(2):e0004423. doi:10.1371/journal.pntd.0004423

147. Wu Y, Ellis RD, Shaffer D, Fontes E, Malkin EM, Mahanty S, et al. Phase 1 trial of malaria transmission blocking vaccine candidates Pfs 25 and
Pvs25 formulated with montanide ISA 51. PLoS One (2008) 3(7):e2636. doi:10.1371/journal.pone.0002636

148. Malkin EM, Durbin AP, Diemert DJ, Sattabongkot J, Wu Y, Miura K, et al. Phase 1 vaccine trial of Pvs25H: a transmission blocking vaccine for Plasmodium vivax malaria. Vaccine (2005) 23(24):3131-8. doi:10.1016/ j.vaccine.2004.12.019

149. Bell BA, Wood JF, Bansal R, Ragab H, Cargo J, Washington MA, et al. Process development for the production of an E. coli produced clinical grade recombinant malaria vaccine for Plasmodium vivax. Vaccine (2009) 27(9):1448-53. doi:10.1016/j.vaccine.2008.12.027

150. Yadava A, Sattabongkot J, Washington MA, Ware LA, Majam V, Zheng $\mathrm{H}$, et al. A novel chimeric Plasmodium vivax circumsporozoite protein induces biologically functional antibodies that recognize both VK210 and VK247 sporozoites. Infect Immun (2007) 75(3):1177-85. doi:10.1128/IAI. 01667-06

151. Cheng Y, Ito D, Sattabongkot J, Lim CS, Kong D-H, Ha K-S, et al. Serological responses to a soluble recombinant chimeric Plasmodium vivax circumsporozoite protein in VK210 and VK247 population. Malar J (2013) 12(1):1. doi:10.1186/1475-2875-12-323

152. Wilson KL, Xiang SD, Plebanski M. Montanide, Poly I:C and nanoparticle based vaccines promote differential suppressor and effector cell expansion: a study of induction of CD8 T cells to a minimal Plasmodium berghei epitope. Front Microbiol (2015) 6:29. doi:10.3389/fmicb.2015.00029

153. Yadava A, Hall CE, Sullivan JS, Nace D, Williams T, Collins WE, et al. Protective efficacy of a Plasmodium vivax circumsporozoite protein-based vaccine in Aotus nancymaae is associated with antibodies to the repeat region. PLoS Negl Trop Dis (2014) 8(10):e3268. doi:10.1371/journal. pntd.0003268

154. Krieg AM, Yi A-K, Matson S, Waldschmidt TJ, Bishop GA, Teasdale R, et al. CpG motifs in bacterial DNA trigger direct B-cell activation. Nature (1995) 374(6522):546-9. doi:10.1038/374546a0

155. Camacho AGA, Teixeira LH, Bargieri DY, Boscardin SB, Soares IDS, Nussenzweig RS, et al. TLR5-dependent immunogenicity of a recombinant fusion protein containing an immunodominant epitope of malarial circumsporozoite protein and the FliC flagellin of Salmonella typhimurium. Mem Inst Oswaldo Cruz (2011) 106:167-71. doi:10.1590/S007402762011000900021

156. Rogers WO, Malik A, Mellouk S, Nakamura K, Rogers MD, Szarfman A, et al. Characterization of Plasmodium falciparum sporozoite surface protein 2. Proc Natl Acad Sci U S A (1992) 89(19):9176-80. doi:10.1073/ pnas.89.19.9176

157. Ogunbanwo JA, Pendyala PR, Malhotra P, Chauhan VS. Expression, purification and characterization of a recombinant Plasmodium vivax thrombospondin related adhesive protein (PvTRAP). Int J Biomed Sci (2006) 2(3):251.

158. Swearingen KE, Lindner SE, Shi L, Shears MJ, Harupa A, Hopp CS, et al. Interrogating the Plasmodium sporozoite surface: identification of surfaceexposed proteins and demonstration of glycosylation on CSP and TRAP by mass spectrometry-based proteomics. PLoS Pathog (2016) 12(4):e1005606. doi:10.1371/journal.ppat.1005606

159. Hafalla JCR, Bauza K, Friesen J, Gonzalez-Aseguinolaza G, Hill AV, Matuschewski K. Identification of targets of CD8+ T cell responses to malaria liver stages by genome-wide epitope profiling. PLoS Pathog (2013) 9(5):e1003303. doi:10.1371/journal.ppat.1003303

160. Longley RJ, Bauza K, Ewer KJ, Hill AV, Spencer AJ. Development of an in vitro assay and demonstration of Plasmodium berghei liver-stage inhibition by TRAP-specific CD8+ T cells. PLoS One (2015) 10(3):e0119880. doi:10.1371/ journal.pone. 0119880

161. Ewer KJ, O’Hara GA, Duncan CJ, Collins KA, Sheehy SH, Reyes-Sandoval A, et al. Protective CD8+ T-cell immunity to human malaria induced by chimpanzee adenovirus-MVA immunisation. Nat Commun (2013) 4:2836. doi: $10.1038 /$ ncomms 3836

162. Castellanos A, Arévalo-Herrera M, Restrepo N, Gulloso L, Corradin G, Herrera S. Plasmodium vivax thrombospondin related adhesion protein: immunogenicity and protective efficacy in rodents and Aotus monkeys. Mem Inst Oswaldo Cruz (2007) 102(3):411-6. doi:10.1590/ S0074-02762007005000047

163. Bauza K, Malinauskas T, Pfander C, Anar B, Jones EY, Billker O, et al. Efficacy of a Plasmodium vivax malaria vaccine using ChAd63 and modified vaccinia Ankara expressing thrombospondin-related anonymous protein 
as assessed with transgenic Plasmodium berghei parasites. Infect Immun (2014) 82(3):1277-86. doi:10.1128/IAI.01187-13

164. Chenet SM, Tapia LL, Escalante AA, Durand S, Lucas C, Bacon DJ. Genetic diversity and population structure of genes encoding vaccine candidate antigens of Plasmodium vivax. Malar J (2012) 11(1):1. doi:10.1186/14752875-11-68

165. Wang Q, Zhao Z, Zhang X, Li X, Zhu M, Li P, et al. Naturally Acquired Antibody Responses to Plasmodium vivax and Plasmodium falciparum Merozoite Surface Protein 1 (MSP1) C-Terminal $19 \mathrm{kDa}$ Domains in an Area of Unstable Malaria Transmission in Southeast Asia. PLoS ONE (2016) 11(3):e0151900. doi:10.1371/journal.pone.0151900

166. Del Portillo HA, Longacre S, Khouri E, David PH. Primary structure of the merozoite surface antigen 1 of Plasmodium vivax reveals sequences conserved between different Plasmodium species. Proc Natl Acad Sci U S A (1991) 88(9):4030-4. doi:10.1073/pnas.88.9.4030

167. del Portillo HA, Gysin J, Mattei DM, Khouri E, Udagama PV, Mendis KN, et al. Plasmodium vivax: cloning and expression of a major blood-stage surface antigen. Exp Parasitol (1988) 67(2):346-53. doi:10.1016/0014-4894(88) 90081-1

168. Freeman RR, Holder AA. Surface antigens of malaria merozoites. A high molecular weight precursor is processed to an $83,000 \mathrm{~mol} \mathrm{wt}$ form expressed on the surface of Plasmodium falciparum merozoites. J Exp Med (1983) 158(5):1647-53. doi:10.1084/jem.158.5.1647

169. Kaslow DC, Kumar S. Expression and immunogenicity of the C-terminus of a major blood-stage surface protein of Plasmodium vivax, Pv200 19, secreted from Saccharomyces cerevisiae. Immunol Lett (1996) 51(3):187-9. doi:10.1016/0165-2478(96)02570-9

170. Han H-J, Park S-G, Kim S-H, Hwang S-Y, Han J, Traicoff J, et al. Epidermal growth factor-like motifs 1 and 2 of Plasmodium vivax merozoite surface protein 1 are critical domains in erythrocyte invasion. Biochem Biophys Res Commun (2004) 320(2):563-70. doi:10.1016/j.bbrc.2004.06.008

171. Soares IS, da Cunha MG, Silva MN, Souza JM, Del Portillo HA, Rodrigues MM. Longevity of naturally acquired antibody responses to the $\mathrm{N}$-and C-terminal regions of Plasmodium vivax merozoite surface protein 1. Am J Trop Med Hyg (1999) 60(3):357-63.

172. Fernandez-Becerra C, Sanz S, Brucet M, Stanisic DI, Alves FP, Camargo EP, et al. Naturally-acquired humoral immune responses against the $\mathrm{N}$-and C-termini of the Plasmodium vivax MSP1 protein in endemic regions of Brazil and Papua New Guinea using a multiplex assay. Malar J (2010) 9(1):1. doi:10.1186/1475-2875-9-29

173. Park CG, Chwae Y-J, Kim J-I, Lee J-H, Hur GM, Jeon BH, et al. Serologic responses of Korean soldiers serving in malaria-endemic areas during a recent outbreak of Plasmodium vivax. Am J Trop Med Hyg (2000) 62(6):720-5.

174. Rosa DS, Iwai LK, Tzelepis F, Bargieri DY, Medeiros MA, Soares IS, et al. Immunogenicity of a recombinant protein containing the Plasmodium vivax vaccine candidate MSP1 19 and two human CD4+ T-cell epitopes administered to non-human primates (Callithrix jacchus jacchus). Microb Infect (2006) 8(8):2130-7. doi:10.1016/j.micinf.2006.03.012

175. Sierra AY, Barrero CA, Rodriguez R, Silva Y, Moncada C, Vanegas $\mathrm{M}$, et al. Splenectomised and spleen intact Aotus monkeys' immune response to Plasmodium vivax MSP-1 protein fragments and their high activity binding peptides. Vaccine (2003) 21(27):4133-44. doi:10.1016/ S0264-410X(03)00455-9

176. Barrero CA, Delgado G, Sierra AY, Silva Y, Parra-Lopez C, Patarroyo MA. Gamma interferon levels and antibody production induced by two PvMSP-1 recombinant polypeptides are associated with protective immunity against P. vivax in Aotus monkeys. Vaccine (2005) 23(31):4048-53. doi:10.1016/ j.vaccine.2005.02.012

177. Dutta S, Ware LA, Barbosa A, Ockenhouse CF, Lanar DE. Purification, characterization, and immunogenicity of a disulfide cross-linked Plasmodium vivax vaccine candidate antigen, merozoite surface protein 1 , expressed in Escherichia coli. Infect Immun (2001) 69(9):5464-70. doi:10.1128/ IAI.69.9.5464-5470.2001

178. Chen J-H, Wang Y, Ha K-S, Lu F, Suh I-B, Lim CS, et al. Measurement of naturally acquired humoral immune responses against the $\mathrm{C}$-terminal region of the Plasmodium vivax MSP1 protein using protein arrays. Parasitol Res (2011) 109(5):1259-66. doi:10.1007/s00436-011-2370-z

179. Cheng Y, Wang Y, Ito D, Kong D-H, Ha K-S, Chen J-H, et al. The Plasmodium vivax merozoite surface protein 1 paralog is a novel erythrocyte-binding ligand of P. vivax. Infect Immun (2013) 81(5):1585-95. doi:10.1128/ IAI.01117-12

180. Galinski MR, Corredor-Medina C, Povoa M, Crosby J, Ingravallo P, Barnwell JW. Plasmodium vivax merozoite surface protein-3 contains coiled-coil motifs in an alanine-rich central domain. Mol Biochem Parasitol (1999) 101(1):131-47. doi:10.1016/S0166-6851(99)00063-8

181. Rayner J, Corredor V, Feldman D, Ingravallo P, Iderabdullah F, Galinski M, et al. Extensive polymorphism in the Plasmodium vivax merozoite surface coat protein MSP- $3 \alpha$ is limited to specific domains. Parasitology (2002) 125(05):393-405. doi:10.1017/S0031182002002317

182. Rayner JC, Huber CS, Feldman D, Ingravallo P, Galinski MR, Barnwell JW. Plasmodium vivax merozoite surface protein PvMSP- $3 \beta$ is radically polymorphic through mutation and large insertions and deletions. Infect Genet Evol (2004) 4(4):309-19. doi:10.1016/j.meegid.2004.03.003

183. Hisaeda H, Saul A, Reece JJ, Kennedy MC, Long CA, Miller LH, et al. Merozoite surface protein 3 and protection against malaria in Aotus nancymai monkeys. J Infect Dis (2002) 185(5):657-64. doi:10.1086/339187

184. Audran R, Cachat M, Lurati F, Soe S, Leroy O, Corradin G, et al. Phase I malaria vaccine trial with a long synthetic peptide derived from the merozoite surface protein 3 antigen. Infect Immun (2005) 73(12):8017-26. doi:10.1128/ IAI.73.12.8017-8026.2005

185. Vargas-Serrato E, Barnwell JW, Ingravallo P, Perler FB, Galinski MR. Merozoite surface protein- 9 of Plasmodium vivax and related simian malaria parasites is orthologous to p101/ABRA of P. falciparum. Mol Biochem Parasitol (2002) 120(1):41-52. doi:10.1016/S0166-6851(01)00433-9

186. Oliveira-Ferreira J, Vargas-Serrato E, Barnwell JW, Moreno A, Galinski MR. Immunogenicity of Plasmodium vivax merozoite surface protein-9 recombinant proteins expressed in E. coli. Vaccine (2004) 22(15-16):2023-30. doi:10.1016/j.vaccine.2003.07.021

187. Horuk R, Chitnis CE, Darbonne WC, Colby TJ, Rybicki A, Hadley TJ, et al. A receptor for the malarial parasite Plasmodium vivax: the erythrocyte chemokine receptor. Science (1993) 261(5125):1182-4. doi:10.1126/science. 7689250

188. Wertheimer SP, Barnwell JW. Plasmodium vivax interaction with the human Duffy blood group glycoprotein: identification of a parasite receptor-like protein. Exp Parasitol (1989) 69(3):340-50. doi:10.1016/0014-4894(89) 90083-0

189. Fang X, Kaslow DC, Adams JH, Miller LH. Cloning of the Plasmodium vivax Duffy receptor. Mol Biochem Parasitol (1991) 44(1):125-32. doi:10.1016/0166-6851(91)90228-X

190. Adams JH, Sim BK, Dolan SA, Fang X, Kaslow DC, Miller LH. A family of erythrocyte binding proteins of malaria parasites. Proc Natl Acad Sci U S A (1992) 89(15):7085-9. doi:10.1073/pnas.89.15.7085

191. Chitnis CE, Miller LH. Identification of the erythrocyte binding domains of Plasmodium vivax and Plasmodium knowlesi proteins involved in erythrocyte invasion. J Exp Med (1994) 180(2):497-506. doi:10.1084/jem. 180.2.497

192. Ntumngia FB, Adams JH. Design and immunogenicity of a novel synthetic antigen based on the ligand domain of the Plasmodium vivax Duffy binding protein. Clin Vaccine Immunol (2012) 19(1):30-6. doi:10.1128/ CVI.05466-11

193. Cole-Tobian JL, Michon P, Biasor M, Richards JS, Beeson JG, Mueller I, et al. Strain-specific Duffy binding protein antibodies correlate with protection against infection with homologous compared to heterologous Plasmodium vivax strains in Papua New Guinean children. Infect Immun (2009) 77(9):4009-17. doi:10.1128/IAI.00158-09

194. Ceravolo I, Sanchez B, Sousa T, Guerra B, Soares I, Braga E, et al. Naturally acquired inhibitory antibodies to Plasmodium vivax Duffy binding protein are short-lived and allele-specific following a single malaria infection. Clin Exp Immunol (2009) 156(3):502-10. doi:10.1111/j.1365-2249. 2009.03931.x

195. Chootong P, Panichakul T, Permmongkol C, Barnes SJ, Udomsangpetch $\mathrm{R}$, Adams JH. Characterization of inhibitory anti-Duffy binding protein II immunity: approach to Plasmodium vivax vaccine development in Thailand. PLoS One (2012) 7(4):e35769. doi:10.1371/journal.pone.0035769

196. Michon P, Fraser T, Adams JH. Naturally Acquired and vaccine-elicited antibodies block erythrocyte cytoadherence of the Plasmodium vivax Duffy binding protein. Infect Immun (2000) 68(6):3164-71. doi:10.1128/ IAI.68.6.3164-3171.2000 
197. Chootong P, McHenry AM, Ntumngia FB, Sattabongkot J, Adams JH. The association of Duffy binding protein region II polymorphisms and its antigenicity in Plasmodium vivax isolates from Thailand. Parasitol Int (2014) 63(6):858-64. doi:10.1016/j.parint.2014.07.014

198. Xainli J, Baisor M, Kastens W, Bockarie M, Adams JH, King CL. Agedependent cellular immune responses to Plasmodium vivax Duffy binding protein in humans. J Immunol (2002) 169(6):3200-7. doi:10.4049/ jimmunol.169.6.3200

199. Xainli J, Cole-Tobian JL, Baisor M, Kastens W, Bockarie M, Yazdani SS, et al. Epitope-specific humoral immunity to Plasmodium vivax Duffy binding protein. Infect Immun (2003) 71(5):2508-15. doi:10.1128/ IAI.71.5.2508-2515.2003

200. VanBuskirk KM, Sevova E, Adams JH. Conserved residues in the Plasmodium vivax Duffy-binding protein ligand domain are critical for erythrocyte receptor recognition. Proc Natl Acad Sci U S A (2004) 101(44):15754-9. doi:10.1073/pnas.0405421101

201. VanBuskirk KM, Tobian JLC, Baisor M, Sevova ES, Bockarie M, King CL, et al. Antigenic drift in the ligand domain of Plasmodium vivax Duffy binding protein confers resistance to inhibitory antibodies. J Infect Dis (2004) 190(9):1556-62. doi:10.1086/424852

202. Saravia C, Martinez P, Granados DS, Lopez C, Reyes C, Patarroyo MA. Identification and evaluation of universal epitopes in Plasmodium vivax Duffy binding protein. Biochem Biophys Res Commun (2008) 377(4):1279-83. doi:10.1016/j.bbrc.2008.10.153

203. Martinez P, Lopez C, Saravia C, Vanegas M, Patarroyo MA. Evaluation of the antigenicity of universal epitopes from PvDBPII in individuals exposed to Plasmodium vivax malaria. Microbes Infect (2010) 12(14):1188-97. doi:10.1016/j.micinf.2010.08.007

204. Maestre A, Muskus C, Duque V, Agudelo O, Liu P, Takagi A, et al. Acquired antibody responses against Plasmodium vivax infection vary with host genotype for Duffy antigen receptor for chemokines (DARC). PLoS One (2010) 5(7):e11437. doi:10.1371/journal.pone.0011437

205. Waters AP, Thomas A, Deans J, Mitchell G, Hudson DE, Miller LH, et al. A merozoite receptor protein from Plasmodium knowlesi is highly conserved and distributed throughout Plasmodium. J Biol Chem (1990) 265(29):17974-9.

206. Cheng Q, Saul A. Sequence analysis of the apical membrane antigen I (AMA-1) of Plasmodium vivax. Mol Biochem Parasitol (1994) 65(1):183-7. doi:10.1016/0166-6851(94)90127-9

207. Hodder AN, Crewther PE, Matthew ML, Reid GE, Moritz RL, Simpson RJ, et al. The disulfide bond structure of Plasmodium apical membrane antigen-1. J Biol Chem (1996) 271(46):29446-52. doi:10.1074/jbc.271.46.29446

208. Remarque EJ, Faber BW, Kocken CH, Thomas AW. Apical membrane antigen 1: a malaria vaccine candidate in review. Trends Parasitol (2008) 24(2):74-84. doi:10.1016/j.pt.2007.12.002

209. Kocken CH, Dubbeld MA, Van Der Wel A, Pronk JT, Waters AP, Langermans JA, et al. High-level expression of Plasmodium vivax apical membrane antigen 1 (AMA-1) in Pichia pastoris: strong immunogenicity in Macaca mulatta immunized with P. vivax AMA-1 and adjuvant SBAS2. Infect Immun (1999) 67(1):43-9.

210. Bouillet LÉM, Dias MO, Dorigo NA, Moura AD, Russell B, Nosten F, et al. Long-term humoral and cellular immune responses elicited by a heterologous Plasmodium vivax apical membrane antigen 1 protein prime/adenovirus boost immunization protocol. Infect Immun (2011) 79(9):3642-52. doi:10.1128/IAI.05048-11

211. Salavatifar M, Zakeri S, Roodbari NH, Djadid ND. High-level expression, purification and characterization of a recombinant Plasmodium vivax apical membrane antigen 1: implication for vivax malaria vaccine development. Cell $J(2015)$ 17(3):520.

212. Salavatifar M, Zakeri S, Abouie Mehrizi A, Mirkhazemi S, Dinparast Djadid N. Evaluation of naturally acquired antibody responses to two variant forms of Plasmodium vivax apical membrane antigen-1 in individuals living in areas of low and unstable malaria transmission of Iran. Arch Iran Med (2015) 18(12):834-43.

213. Bueno LL, Lobo FP, Morais CG, Mourão LC, de Ávila RAM, Soares IS, et al. Identification of a highly antigenic linear B cell epitope within Plasmodium vivax apical membrane antigen 1 (AMA-1). PLoS One (2011) 6(6):e21289. doi:10.1371/journal.pone.0021289
214. Gentil F, Bargieri DY, Leite JA, Francoso KS, Patricio MB, Espindola NM, et al. A recombinant vaccine based on domain II of Plasmodium vivax apical membrane antigen 1 induces high antibody titres in mice. Vaccine (2010) 28(38):6183-90. doi:10.1016/j.vaccine.2010.07.017

215. Li J, Han E-T. Dissection of the Plasmodium vivax reticulocyte binding-like proteins (PvRBPs). Biochem Biophys Res Commun (2012) 426(1):1-6. doi:10.1016/j.bbrc.2012.08.055

216. Galinski M, Barnwell J. Plasmodium vivax: merozoites, invasion of reticulocytes and considerations for malaria vaccine development. Parasitol Today (1996) 12(1):20-9. doi:10.1016/0169-4758(96)80641-7

217. Galinski MR, Medina CC, Ingravallo P, Barnwell JW. A reticulocyte-binding protein complex of Plasmodium vivax merozoites. Cell (1992) 69(7):1213-26. doi:10.1016/0092-8674(92)90642-P

218. Galinski MR, Xu M, Barnwell JW. Plasmodium vivax reticulocyte binding protein-2 (PvRBP-2) shares structural features with PvRBP-1 and the Plasmodium yoelii $235 \mathrm{kDa}$ rhoptry protein family. Mol Biochem Parasitol (2000) 108(2):257-62. doi:10.1016/S0166-6851(00)00219-X

219. Hietanen J, Chim-ong A, Chiramanewong T, Gruszczyk J, Roobsoong W, Tham W-H, et al. Gene models, expression repertoire, and immune response of Plasmodium vivax reticulocyte binding proteins. Infect Immun (2016) 84(3):677-85. doi:10.1128/IAI.01117-15

220. Prajapati SK, Singh OP. Insights into the invasion biology of Plasmodium vivax. Front Cell Infect Microbiol (2013) 3:8. doi:10.3389/fcimb.2013.00008

221. Franca CT, He WQ, Gruszczyk J, Lim NT, Lin E, Kiniboro B, et al. Plasmodium vivax reticulocyte binding proteins are key targets of naturally acquired immunity in young Papua New Guinean children. PLoS Negl Trop Dis (2016) 10(9):e0005014. doi:10.1371/journal.pntd.0005014

222. Cantor EM, Lombo TB, Cepeda A, Espinosa AM, Barrero CA, Guzmán F, et al. Plasmodium vivax: functional analysis of a highly conserved PvRBP-1 protein region. Mol Biochem Parasitol (2001) 117(2):229-34. doi:10.1016/ S0166-6851(01)00355-3

223. Urquiza M, Patarroyo MA, Marí V, Ocampo M, Suarez J, Lopez R, et al. Identification and polymorphism of Plasmodium vivax RBP-1 peptides which bind specifically to reticulocytes. Peptides (2002) 23(12):2265-77. doi:10.1016/S0196-9781(02)00267-X

224. Rojas-Caraballo J, Delgado G, Rodriguez R, Patarroyo MA. The antigenicity of a Plasmodium vivax reticulocyte binding protein-1 (PvRBP1) recombinant fragment in humans and its immunogenicity and protection studies in Aotus monkeys. Vaccine (2007) 25(18):3713-21. doi:10.1016/j.vaccine.2006. 12.041

225. Perez-Leal O, Sierra AY, Barrero CA, Moncada C, Martinez P, Cortes J, et al. Identifying and characterising the Plasmodium falciparum merozoite surface protein 10 Plasmodium vivax homologue. Biochem Biophys Res Commun (2005) 331(4):1178-84. doi:10.1016/j.bbrc.2005.04.031

226. Giraldo MA, Arevalo-Pinzon G, Rojas-Caraballo J, Mongui A, Rodriguez $\mathrm{R}$, Patarroyo MA. Vaccination with recombinant Plasmodium vivax MSP-10 formulated in different adjuvants induces strong immunogenicity but no protection. Vaccine (2009) 28(1):7-13. doi:10.1016/j.vaccine. 2009.09.046

227. Cheng Y, Wang B, Sattabongkot J, Lim CS, Tsuboi T, Han E-T. Immunogenicity and antigenicity of Plasmodium vivax merozoite surface protein 10. Parasitol Res (2014) 113(7):2559-68. doi:10.1007/s00436-014-3907-8

228. Mongui A, Angel DI, Gallego G, Reyes C, Martinez P, Guhl F, et al. Characterization and antigenicity of the promising vaccine candidate Plasmodium vivax 34kDa rhoptry antigen (Pv34). Vaccine (2009) 28(2):41521. doi:10.1016/j.vaccine.2009.10.034

229. Moreno-Perez DA, Montenegro M, Patarroyo ME, Patarroyo MA. Identification, characterization and antigenicity of the Plasmodium vivax rhoptry neck protein 1 (PvRON1). Malar J (2011) 10:314. doi:10.1186/ 1475-2875-10-314

230. Cheng Y, Li J, Ito D, Kong DH, Ha KS, Lu F, et al. Antigenicity and immunogenicity of PvRALP1, a novel Plasmodium vivax rhoptry neck protein. Malar $J$ (2015) 14:186. doi:10.1186/s12936-015-0698-Z

231. Bergmann-Leitner ES, Mease RM, de la Vega P, Savranskaya T, Polhemus M, Ockenhouse C, et al. Immunization with pre-erythrocytic antigen CelTOS from Plasmodium falciparum elicits cross-species protection against heterologous challenge with Plasmodium berghei. PLoS One (2010) 5(8):e12294. doi:10.1371/journal.pone.0012294 
232. Kariu T, Ishino T, Yano K, Chinzei Y, Yuda M. CelTOS, a novel malarial protein that mediates transmission to mosquito and vertebrate hosts. $\mathrm{Mol}$ Microbiol (2006) 59(5):1369-79. doi:10.1111/j.1365-2958.2005.05024.x

233. Longley RJ, Reyes-Sandoval A, Montoya-Díaz E, Dunachie S, Kumpitak C, Nguitragool W, et al. Acquisition and longevity of antibodies to Plasmodium vivax preerythrocytic antigens in Western Thailand. Clin Vaccine Immunol (2016) 23(2):117-24. doi:10.1128/CVI.00501-15

234. Peiris JS, Premawansa S, Ranawaka MB, Udagama PV, Munasinghe YD, Nanayakkara MV, et al. Monoclonal and polyclonal antibodies both block and enhance transmission of human Plasmodium vivax malaria. Am J Trop Med Hyg (1988) 39(1):26-32.

235. Hisaeda H, Stowers AW, Tsuboi T, Collins WE, Sattabongkot JS, Suwanabun $\mathrm{N}$, et al. Antibodies to malaria vaccine candidates Pvs25 and Pvs28 completely block the ability of Plasmodium vivax to infect mosquitoes. Infect Immun (2000) 68(12):6618-23. doi:10.1128/IAI.68.12.66186623.2000

236. Hisaeda H, Collins WE, Saul A, Stowers AW. Antibodies to Plasmodium vivax transmission-blocking vaccine candidate antigens Pvs25 and Pvs28 do not show synergism. Vaccine (2001) 20(5-6):763-70. doi:10.1016/ S0264-410X(01)00402-9

237. Sattabongkot J, Tsuboi T, Hisaeda H, Tachibana M, Suwanabun N, Rungruang $\mathrm{T}$, et al. Blocking of transmission to mosquitoes by antibody to Plasmodium vivax malaria vaccine candidates Pvs 25 and Pvs28 despite antigenic polymorphism in field isolates. Am J Trop Med Hyg (2003) 69(5):536-41.

238. Arevalo-Herrera M, Solarte Y, Yasnot MF, Castellanos A, Rincon A, Saul A, et al. Induction of transmission-blocking immunity in Aotus monkeys by vaccination with a Plasmodium vivax clinical grade PVS25 recombinant protein. Am J Trop Med Hyg (2005) 73(5 Suppl):32-7.

239. Miura K, Keister DB, Muratova OV, Sattabongkot J, Long CA, Saul A. Transmission-blocking activity induced by malaria vaccine candidates Pfs25/ Pvs25 is a direct and predictable function of antibody titer. Malar J (2007) 6:107. doi:10.1186/1475-2875-6-107

240. Saul A, Hensmann M, Sattabongkot J, Collins WE, Barnwell JW, Langermans JA, et al. Immunogenicity in rhesus of the Plasmodium vivax mosquito stage antigen Pvs25H with alhydrogel and montanide ISA 720. Parasite Immunol (2007) 29(10):525-33. doi:10.1111/j.1365-3024.2007. 00971.x

241. Blagborough AM, Musiychuk K, Bi H, Jones RM, Chichester JA, Streatfield $\mathrm{S}$, et al. Transmission blocking potency and immunogenicity of a plantproduced Pvs25-based subunit vaccine against Plasmodium vivax. Vaccine (2016) 34(28):3252-9. doi:10.1016/j.vaccine.2016.05.007

242. Espinosa AM, Sierra AY, Barrero CA, Cepeda LA, Cantor EMA, Lombo TB, et al. Expression, polymorphism analysis, reticulocyte binding and serological reactivity of two Plasmodium vivax MSP-1 protein recombinant fragments. Vaccine (2003) 21(11):1033-43. doi:10.1016/ S0264-410X(02)00660-6

243. Tanabe K, Escalante A, Sakihama N, Honda M, Arisue N, Horii T, et al. Recent independent evolution of MSP1 polymorphism in Plasmodium vivax and related simian malaria parasites. Mol Biochem Parasitol (2007) 156(1):74-9. doi:10.1016/j.molbiopara.2007.07.002

244. Achtman A, Bull P, Stephens R, Langhorne J. Longevity of the immune response and memory to blood-stage malaria infection. In: Langhorne J, editor. Immunology and Immunopathogenesis of Malaria. Berlin, Heidelberg: Springer (2005). p. 71-102.

245. Villegas-Mendez A, Inkson CA, Shaw TN, Strangward P, Couper KN. Longlived CD4+ IFN- $\gamma+$ T cells rather than short-lived CD4+ IFN- $\gamma+$ IL- $10+$ T cells initiate rapid IL-10 production to suppress anamnestic T cell responses during secondary malaria infection. J Immunol (2016) 197(8):3152-64. doi:10.4049/jimmunol.1600968

246. Patarroyo ME, Alba MP, Reyes C, Rojas-Luna R, Patarroyo MA. The Malaria Parasite's Achilles' Heel: functionally-relevant invasion structures. Curr Issues Mol Biol (2015) 18:11-20. doi:10.21775/cimb.018.011

247. Cifuentes G, Bermudez A, Rodriguez R, Patarroyo M, Patarroyo M. Shifting the polarity of some critical residues in malarial peptides' binding to host cells is a key factor in breaking conserved antigens' code of silence. Med Chem (2008) 4(3):278-92. doi:10.2174/157340608784325160

248. Patarroyo ME, Bermudez A, Patarroyo MA. Structural and immunological principles leading to chemically synthesized, multiantigenic, multistage, minimal subunit-based vaccine development. Chem Rev (2011) 111(5):3459-507. doi:10.1021/cr100223m

249. Patarroyo MA, Bermudez A, Lopez C, Yepes G, Patarroyo ME. 3D analysis of the TCR/pMHCII complex formation in monkeys vaccinated with the first peptide inducing sterilizing immunity against human malaria. PLoS One (2010) 5(3):e9771. doi:10.1371/journal.pone.0009771

Conflict of Interest Statement: The authors declare that the research was conducted in the absence of any commercial or financial relationships that could be construed as a potential conflict of interest.

Copyright (c) 2017 López, Yepes-Pérez, Hincapié-Escobar, Díaz-Arévalo and Patarroyo. This is an open-access article distributed under the terms of the Creative Commons Attribution License (CC BY). The use, distribution or reproduction in other forums is permitted, provided the original author(s) or licensor are credited and that the original publication in this journal is cited, in accordance with accepted academic practice. No use, distribution or reproduction is permitted which does not comply with these terms. 